\title{
Estimation of seismic ground motions using deterministic approach for major cities of Gujarat
}

\author{
J. Shukla and D. Choudhury \\ Department of Civil Engineering, Indian Institute of Technology Bombay, Powai, Mumbai, 400076, India \\ Correspondence to: D. Choudhury (dc@civil.iitb.ac.in)
}

Received: 10 January 2011 - Revised: 30 March 2011 - Accepted: 16 May 2011 - Published: 26 June 2012

\begin{abstract}
A deterministic seismic hazard analysis has been carried out for various sites of the major cities (Ahmedabad, Surat, Bhuj, Jamnagar and Junagadh) of the Gujarat region in India to compute the seismic hazard exceeding a certain level in terms of peak ground acceleration (PGA) and to estimate maximum possible PGA at each site at bed rock level. The seismic sources in Gujarat are very uncertain and recurrence intervals of regional large earthquakes are not well defined. Because the instrumental records of India specifically in the Gujarat region are far from being satisfactory for modeling the seismic hazard using the probabilistic approach, an attempt has been made in this study to accomplish it through the deterministic approach. In this regard, all small and large faults of the Gujarat region were evaluated to obtain major fault systems. The empirical relations suggested by earlier researchers for the estimation of maximum magnitude of earthquake motion with various properties of faults like length, surface area, slip rate, etc. have been applied to those faults to obtain the maximum earthquake magnitude. For the analysis, seven different ground motion attenuation relations (GMARs) of strong ground motion have been utilized to calculate the maximum horizontal ground accelerations for each major city of Gujarat. Epistemic uncertainties in the hazard computations are accounted for within a logic-tree framework by considering the controlling parameters like $b$ value, maximum magnitude and ground motion attenuation relations (GMARs). The corresponding deterministic spectra have been prepared for each major city for the 50th and 84th percentiles of ground motion occurrence. These deterministic spectra are further compared with the specified spectra of Indian design code IS:1893-Part I (2002) to validate them for further practical use. Close examination of the developed spectra reveals that the expected ground motion values become high for the Kachchh region i.e. Bhuj city and moderate in the Mainland Gujarat, i.e. cities of Surat and Ahmedabad. The seismic ground motion level in the Saurashtra is moderate but marginally differs from that as presently specified in
\end{abstract}

IS:1893-Part I (2002). Based on the present study, the recommended PGA values for the cities studied are $0.13 \mathrm{~g}, 0.15 \mathrm{~g}$, $0.64 \mathrm{~g}, 0.14 \mathrm{~g}$ and $0.2 \mathrm{~g}$ for Ahmedabad city, Surat City, Bhuj City, Jamnagar City and Junagadh city, respectively. The prepared spectra can be further used for seismic resistant design of structures within the above major city boundaries of $\mathrm{Gu}$ jarat to quantify seismic loading on structures.

\section{Introduction}

Proper determination of the peak horizontal ground acceleration for designing the earthquake-resistant structures in earthquake-prone regions is essential. In country like India with huge populations, the utmost care must be taken for such estimation of seismic ground motion for seismically active regions like the Himalayian belt, the Kachchh region, etc. The current practice in India for assigning the earthquake load for the design of structures is to utilize the seismic hazard zonation map given in the Indian standard design code IS:1893-Part I (2002), in which India is divided into four subclasses of seismic zones. The assigned peak ground acceleration (PGA) values on that map are $0.08 \mathrm{~g}, 0.16 \mathrm{~g}, 0.24 \mathrm{~g}$ and $0.32 \mathrm{~g}$ for Zones, II, III, IV and V respectively. The seismic zonation map for the Gujarat region is shown in Fig. 1. In the seismic zonation map, the transition from one seismic zone to the adjacent one is rather drastic; it is created by either dropping or increasing the ground acceleration by $0.08 \mathrm{~g}$. Also, the estimation for seismic ground motions in various major cities of Gujarat is still not consistent with the tectonic framework for Gujarat. Hence, in this paper an attempt has been made to estimate the seismic ground motions for the entire region of Gujarat including some typical major cities representing all seismic zones.

The Gujarat region is located within the tectonic plate of India, about $500 \mathrm{~km}$ from a transform plate boundary (Bendick et al., 2001) (Fig. 1). The region has also experienced 
several damaging moderate-sized earthquakes with moment magnitudes between 5 and 6 (Bendick et al., 2001, Petersen et al., 2004, Choudhury and Shukla, 2011). Nine of these moderate earthquakes have occurred during the past $155 \mathrm{yr}$ in this region with an average of about one event every $17 \mathrm{yr}$. Large and moderate earthquakes are likely to repeat in the future and it is essential to assess the hazard in order to aid engineers and public officials in making decisions that will influence economic and life safety policies for the Gujarat region (Petersen et al., 2004). During the year 2008, 1842 shocks of moment magnitude of 0.5 to 4.4 were recorded in Gujarat. Figure 2 illustrates the locations of epicenters for various earthquakes recorded during 2008 through the Gujarat State Seismic Network (GS-Net), recently established by the Institute of Seismological Research (ISR), Gujarat.

The present study aims to carry out deterministic seismic hazard analysis for a few major cities of Gujarat. Typical five major city locations viz. Ahmedabad, Surat, Jamnagar, Bhuj and Junagadh have been selected for the present study. The selection of these five sites is primarily based on the fact that all these sites represent all the three parts of the investigated area, i.e. Kachchh, Saurashtra and the Mainland region of Gujarat and within that particular area, they are also the hubs of commercial/administrative activities. Moreover, these locations also represent the different earthquake zonations given in IS: 1893 - Part I (2002) which will facilitate the comparison of the outcome of this study with provisions of the code. The outcome of the present study consists of deterministic response spectra of the horizontal component of ground motion for different natural periods of structures for the particular city for the reference 50 percentile (median) and 84 percentile of earthquake occurrence, respectively.

\section{Methodology}

Following Yadav et al. (2008), in the present study, the entire Gujarat region is divided into three seismogenic regions on the basis of seismicity, tectonics and geomorphology, namely Saurashtra, Mainland Gujarat and Kachchh. Available seismotectonic and geological criteria are combined to prepare a possible fault map which is then put together with the available earthquake catalogue to obtain fault recurrence relations from regional earthquake recurrence relations. The maximum magnitude associated with fault can be determined either from the observed maximum earthquake in a nearby area from the earthquake catalogue data or can be calculated through empirical correlations between key fault parameters (fault rupture length, fault displacement and fault area) and magnitude. The available relationships given by different researchers, such as Bonilla et al. (1984), Nowroozi (1985), Slemmons et al. (1989), and Wells and Coppersmith (1994) have been used for the present study in order to decide the maximum magnitude for particular fault. These parameters are finally combined with seven Ground Motion Attenua- tion Relations (GMARs) within a probabilistic framework to identify the most probable deterministic ground motion values at a given site. The Epistemic uncertainty in the present analysis has been tackled within a logic-tree framework considering a few controlling parameters like region specific bvalue, maximum magnitude of earthquake, and ground motion attenuation relations (GMARs).

\section{Seismotectonic settings}

The collision process of the Indian plate with the Eurasian plate is still underway at a rate of $45 \mathrm{~mm} \mathrm{year}^{-1}$, inducing an anticlockwise rotation of the plate (Bilham, 2004). Apart from the active seismic sources at the plate boundary (i.e. Himalayan arc), most of Peninsular India (PI) has been considered as a low seismic zone until the occurrence of some surprising and damaging earthquakes in the recent past (e.g. Koyna, 1967; Latur, 1993; Jabalpur, 1997, and Bhuj, 2001). From the point of view of physiography, the Gujarat region of India is comprised of three distinct zones: Kachchh, Saurashtra, and Mainland Gujarat (Chopra et al., 2010). The region is a junction of three tectonic rifts: Kachchh, Cambay and Narmada with several active faults (Biswas 1987, 2005; Talwani and Gangopadhayay, 2001). The seismicity of the Gujarat state is characterized by a relatively high frequency of large earthquakes but a relatively low frequency of moderate earthquakes, particuarly in the Kachchh region. The seismic characteristics of the Gujarat state has been divided into three regions (e.g. Kachchh, Saurashtra and Mainland Gujarat) to study the seismicity within the regions.

\subsection{Kachchh}

The Kachchh basin is a western margin pericratonic rift basin of India (Biswas 1987, 2005). The Kachchh region is considered to be bound between the two extensional faults, namely the south-dipping Nagar Parkar Fault (along the Pakistan border) in the North and the north-dipping Kathiawar Fault in the South (Rastogi, 2004). Several researchers has described the seismotectonic of Kachchh mainly, Biswas and Deshpande (1970), Biswas (1987, 2005), Sukhtankar et al. (1993), Malik et al. (1999), Rastogi et al. (2001), Thakur and Wesnousky (2002), Bodin and Horton (2004), Mandal et al. (2008), Chopra et al. (2010). The Kachchh region has a history of active seismicity with several large damaging earthquakes in the magnitude of 6 to 7 ranging over the last several hundred years (Quittmeyer and Jacob, 1979, Rajendran and Rajendran, 2001). The occurrence of the $M_{\mathrm{w}}=7.6$ Bhuj 2001earthquake less than two centuries after the $M \geq 7.8$ Allah Bund 1819 earthquake has been considered by some investigators to represent a short recurrence interval for earthquakes in Peninsular India. The seismic moments for the past earthquakes yield a strain of $10^{-6}$, 


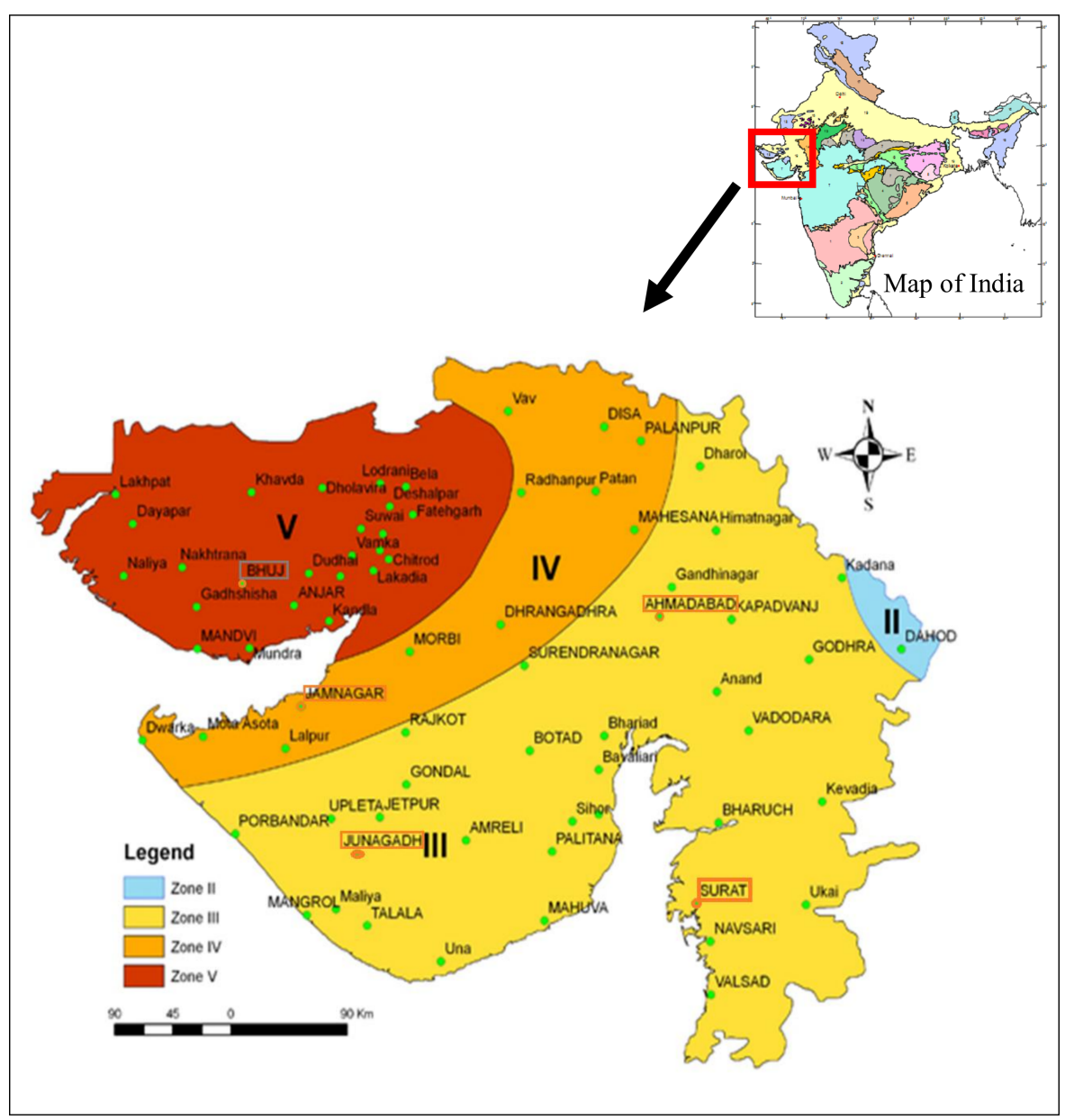

Fig. 1. Geographical location of the Gujarat region in India (highlighed in inset) and seismic zonation map for the Gujarat region (cities under consideration in present study highlighted by red enclosed region). (Ref figure from ISR web site-www.isr.gujarat.gov.in, last accessed on 10 October 2010.)

consistent with the return period of $180 \mathrm{yr}$ in the region or $800 \mathrm{yr}$ on individual faults (Rajendran et al., 2001; Rajendran and Rajendran, 2001). The major faults of the Kutch region are trending E-W that include Allah Bund Fault, Island Belt Fault, Kutch Mainland fault (KMF) and Katrol Hill fault. The north- dipping Allah Bund fault was associated with the 1819 earthquake. The Island Belt Fault, along which there are situated several uplifts seen as islands in the Great Rann of Kutch, is associated with some magnitude 5 earthquakes. The KMF extending for $125 \mathrm{~km}$ is a reverse fault and has a structural displacement of $2-3 \mathrm{~km}$. The 2001 earthquake occurred along a hidden fault named the North Wagad fault (Rastogi, 2001), situated about $25 \mathrm{~km}$ north of KMF and alongside which the Banni Plains area is inferred to be uplifting. Petersen et al. (2004) tested the sensitivity of seismic hazard to three fault source models for the Kachchh region and observed the recurrence intervals of $266-533 \mathrm{yr}$ on one of these faults. Yadav et al. (2008) and Tripathi (2006) worked out a probabilistic hazard assessment for this region based on the earthquake recurrence modeling using various probability distributions.

\subsection{Saurashtra}

The Saurashtra region of Gujarat forms a vital geodynamic part of the western continental margin of India. Several places in the Saurashtra region, for example, Junagadh, Dwarka, Rajkot, Paliyad, Ghogha and Bhavnagar have a history of recurring earthquake activity (Figs. 2 and 3) (Bhattacharya et al., 2004; ISR report 08-09). Apart from various studies on a regional scale, some researchers have attempted to look into the local structure and tectonics. Karanth and Sant (1995) gave a detailed account of post-trappean intrusive of plugs and dykes swarms as well as faults and other lineaments in the region. In the North of Bhavnagar, Bhattacharya et. al., 2004, had identified an E-W trending Shihor fault which offsets the N-S trending western Cambay rift fault (Fig. 3). The region is bounded on all four sides 


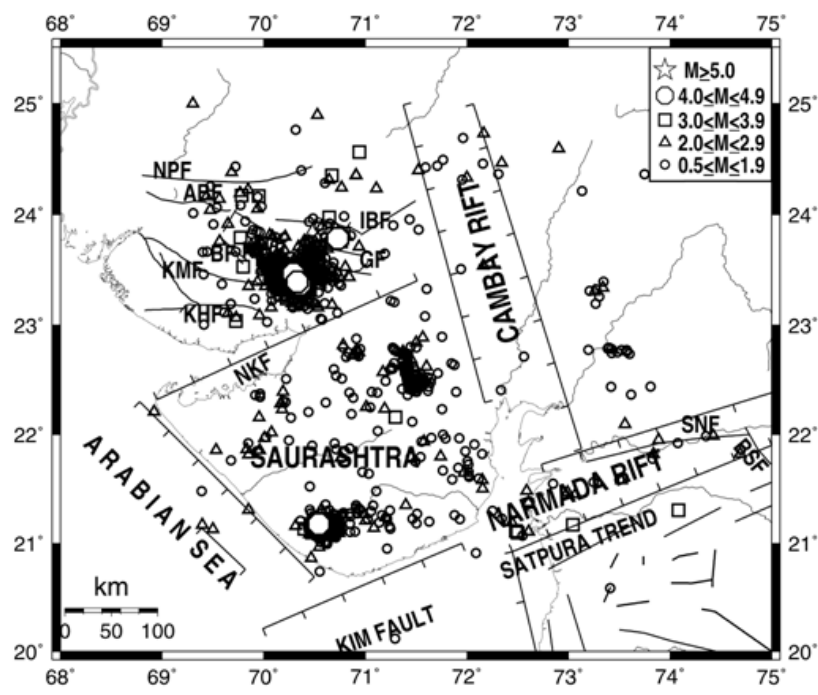

Fig. 2. Epicenters of earthquakes recorded by the ISR (Institute of Seismological Research) in the year 2008. (Reference from Annual report of ISR 08-09, available online on www.isr.gujarat.gov.in).

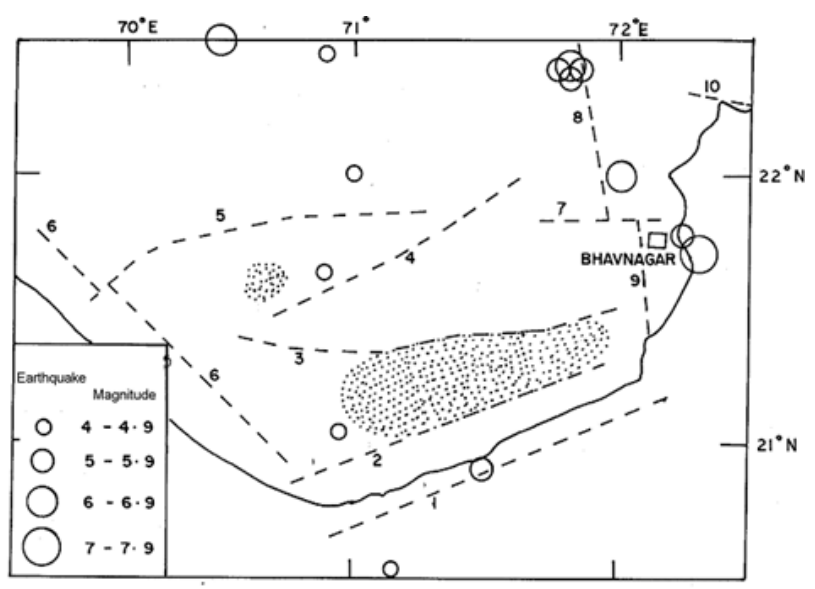

Fig. 3. Location of past earthquakes of magnitude 4 and above. (Note: Dotted areas are dyke zones of swarms. Faults are shown by dashed lines. 1, South Saurashtra fault; 2, Rajula fault; 3, Saverkundala fault; 4, South Junagadh fault; 5, North Junagadh fault; 6, Umrethi fault; 7, Shihor fault; 8, West Cambay basin fault; 9, Eastward offsetted West Cam- bay basin fault, and 10, Camay-Dabhoi fault.) (Bhattacharya et al., 2004).

by major faults namely, the North Kathiawar Fault (NKF) to the north, the extension of the Son-Narmada fault to the south, the WNW-ESE trending West Coast fault system to the west in the Arabian Sea, and the extension of the West Cambay fault to the east (Biswas, 1987, 2005). However, according to past history, only the West Cambay fault in the East near Bhavnagar accommodates moderate seismicity in the last $200 \mathrm{yr}$, while the other faults exhibit weak earthquake activity and were inactive until the recent earthquakes in another region have shown considerable seismicity in the Saurashtra region (Fig. 2), (Yadav et al., 2010).

One strong earthquake $M_{\mathrm{w}}=5.0$ occurring in 1940 in Dwarka (intensity VI) was reported by several researchers (Tandon, 1959; Chandra, 1977; Guha and Basu, 1993). The Junagadh region experienced a shock of $M_{\mathrm{w}}=4.3$ on 3 September 1985 and recently Yadav et al. (2010) has described the recent activities in this region. An offshore earthquake with $M_{\mathrm{W}}=5.0$ was also reported on 24 August 1993 near Rajula. On 3 August 2000, the region of Girnar Hills near Una experienced an earthquake of $M_{\mathrm{w}}=4.3$, which was strongly felt up to Jamnagar. This earthquake activity was associated with two perpendicular faults passing through the epicentral region, namely, the West Cambay and the Shihor faults (Bhattacharya et al., 2004).

\subsection{Mainland Gujarat}

Mainland Gujarat has experienced moderate seismicity covering two rift zones, namely the Narmada rift zone and the Cambay rift zone (Kaila et al., 1980; Biswas, 1987). Presently, the Narmada rift zone is more active than the Cambay rift zone. A total of nine earthquakes of $M_{\mathrm{w}} \geq 5.0$ have occurred in this region. The important earthquakes in this region are Mount Abu $\left(1848, M_{\mathrm{w}}=6.0 ; 1969, M_{\mathrm{w}}=5.5\right)$, Surat $\left(1856, M_{\mathrm{w}}=5.7 ; 1871, M_{\mathrm{w}}=5.0\right.$ and $1935, M_{\mathrm{w}}=$ 5.7), Ahmedabad (1864, $\left.M_{\mathrm{w}}=5.0\right)$, Satpura $\left(1938, M_{\mathrm{w}}=\right.$ 6.0) and Bharuch (1970, $\left.M_{\mathrm{w}}=5.4\right)$ (Yadav et al., 2008). The Broach Earthquake of March 23, 1970 was one of the major intraplate earthquake associated with paleorift zones in the stable continental region of Peninsular India (Chung, 1993). The valleys of the Narmada - Son (NSL) river in India are considered as a major tectonic boundary - a geofracture dividing the Indian shield into a southern peninsular block and a northern foreland block (Biswas, 1982). The NSL has experienced more than 30 earthquakes in the magnitude range of 3.0-6.5 on the Richter scale (Gupta et al., 1997).

\section{Earthquake catalogue}

Various researchers have prepared the earthquake catalogue for the Indian subcontinents (Oldham, 1983; Tandon and Srivastava, 1974; Chandra, 1977; Quittmeyer and Jacob, 1979; Guha and Basu, 1993; Iyengar et al., 1999, Malik et al., 1999, Jaiswal and Sinha, 2007, Yadav et al., 2008) by considering historical and modern earthquakes. The Institute of Seismological Research-Gujarat (ISR) has prepared a compiled earthquake catalogue of the Kachchh, Saurasthra and Mainland Gujarat, bounded by $20-25.5 \mathrm{~N}$ and $68-75 \mathrm{E}$ from the earliest times to March 2008 for all magnitude ranges and has made this available on their web portal (Ref. www.isr.gujarat.gov.in). In the present study, the earthquake catalogue of magnitude $M_{\mathrm{w}} \geq 4$ available on the Institute of Seismological Research's web portal was used in order to 


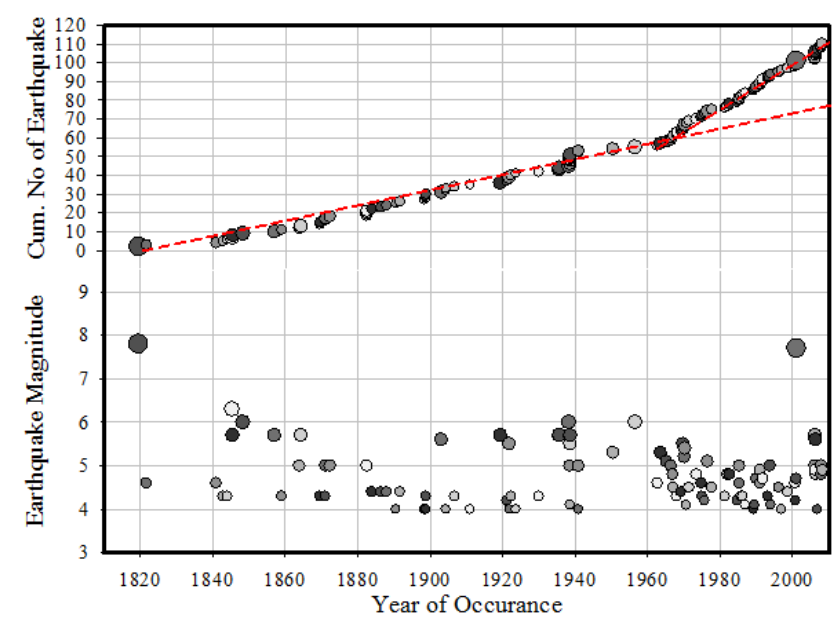

Fig. 4. Catalogue completeness by Cumulative Visual (CUVI) method for Gujarat by using the earthquake catalogue $\left(M_{\mathrm{W}} \geq 4\right)$ available on ISR-Gujarat web site (www.isr.gujarat.gov.in)

find out three parameters: the activity rate, the $b$-value of the Gutenberg-Richter (G-R) relationship, and the observed maximum magnitude of earthquake near the fault. The catalogue was further analyzed for declustering using the static windowing technique (constant spatiotemporal window of 30 days and $30 \mathrm{~km}$ ). After analyzing the earthquake catalogue for declustering, an earthquake catalogue spanning a time period of 1820-2008 for earthquake magnitude $M \geq 4$ was prepared for use in the present study. As seismic instrumentation has been just been initialized in the Gujarat by GS-Net under the umbrella of the Institute of Seismological Research, most of the catalogue events in the prepared catalogue have been taken from historic records only. Historical earthquake records are usually more complete for larger earthquakes than for smaller ones. In the present analysis, the minimum threshold magnitude is assumed as $M_{\mathrm{w}}=4$, and generally events with $M_{\mathrm{w}} \geq 4$ may not remain unnoticed as far as historic data is concerned. Based on this argument, it is reasonable to assume that the earthquake catalogue prepared for $M_{\mathrm{w}} \geq 4$ is complete for its further use for preliminary seismic hazard computations. For checking the completeness correctly, a sufficient number of samples should be available at all possible magnitudes. In the present study, the availability of the data in the Gujarat region is low (after removing the clustered events only, 95 events of $M_{\mathrm{w}} \geq 4$ were available). However, the Cumulative Visual (CUVI) method (Tinti and Mulargia, 1985) was used to check the completeness of the catalogue with these limited data. The CUVI method is based on the visual method for assessing catalogue completeness, based on the plot of the cumulative number of events, which is very easy to apply efficiently for limited event data. Figure 4 represents the cumulative earthquake occurrence in time and space for checking the catalogue completeness. As per Fig. 4, the seismicity rate is uniform from
Table 1. Earthquakes recorded in the year 2008 in the three regions of Gujarat by GS-Net (Ref. Annual Report ISR-Gujarat, 08-09, available online www.isr.gujarat.gov.in).

\begin{tabular}{lccccc}
\hline Region & $M_{\mathrm{W}} \geq 4$ & $\begin{array}{c}M_{\mathrm{W}} \\
(3 \text { to } 3.9)\end{array}$ & $\begin{array}{c}M_{\mathrm{W}} \\
(2 \text { to } 2.9)\end{array}$ & $\begin{array}{c}M_{\mathrm{w}} \\
(1 \text { to } 3.9)\end{array}$ & Total \\
\hline Kachchh & 5 & 52 & 343 & 493 & 893 \\
Saurashtra & 2 & 12 & 221 & 424 & 659 \\
Mainland & - & 3 & 17 & 26 & 46 \\
Total & 7 & 67 & 581 & 943 & 1598 \\
\hline
\end{tabular}

1820 to 1960 but from 1961 to 2008 , the seismicity rate increased. However, the seismicity rate for larger earthquakes in the present study is assumed to be uniform and catalogue is assumed to be complete during the period 1820 to 2008. This is also justified for historic earthquakes where the recorded seismicity differs from the true seismicity. Furthermore, historic earthquake records are usually more complete for larger earthquakes than for smaller ones, which further suggests that the catalogue can be assumed to be complete for $M_{\mathrm{w}} \geq 4$.

The earthquake activities are significant in Gujarat for the recent years and these may be attributed to recent activity along Bhavnagar swarms (2000), Bhuj Earthquake sequence (2001-2008), Jamnagar swarms (2006-2008) and Talala earthquakes (2006-2010) (Table 1). After 2001, seismicity has occurred at several new places in the Saurashtra region, specially in Jamnagar, Surendranagar, and the Talala area of Junagadh which has remained stable within the Saurashtra region.

In the present study, five cities were selected as the target and considering the city as centre, a control region with a radius of $250 \mathrm{~km}$ around the city is taken into account for further seismic hazard computations. From the seismotectonic study and published literature, a possible fault map of this entire Gujarat region has been prepared. Since earthquakes occurring at epicentral distances (i.e. distance between the city and epicenter of earthquake) greater than $250 \mathrm{~km}$ do not generally cause structural damage, the faults located at a maximum distance of $250 \mathrm{~km}$ from a particular site have been not considered as the tectonic features in the present study. A total of 40 major faults, along with major earthquake events which influence seismic hazard at Gujarat, habe been considered in the present study (Fig. 5). A list of these faults is given in Table 2, describing the length of the faults and the controlling region assigned to them for seismic hazard computations.

\section{Maximum magnitude determination}

Once the seismic sources were determined for an area considered for seismic hazard modeling, the next step was the determination of the maximum earthquake magnitude for 
Table 2. Fault characteristics, weighting functions and maximum magnitude for faults used in Seismic Hazard Calculations.

\begin{tabular}{|c|c|c|c|c|c|c|c|c|c|c|c|c|c|}
\hline Sr. No. & $\begin{array}{l}\text { Name } \\
\text { of fault }\end{array}$ & $\begin{array}{l}\text { Length } \\
\text { in } \mathrm{km}\end{array}$ & $\alpha_{i}$ & $x_{i}$ & $N_{i}(m)_{0}$ & $\beta$ & $\begin{array}{l}\text { Rupture } \\
\text { Length } \\
=\mathrm{L} / 3\end{array}$ & $\begin{array}{l}\text { Bonilla } \\
(1984)\end{array}$ & $\begin{array}{c}\text { Nowroozi } \\
(1984)\end{array}$ & $\begin{array}{l}\text { Slemmons } \\
\text { (1982) }\end{array}$ & $\begin{array}{c}\text { W\&C } \\
(1994)\end{array}$ & $\begin{array}{c}\text { Max } \\
\text { magnitude }\end{array}$ & $\begin{array}{l}\text { Controlling } \\
\text { region }\end{array}$ \\
\hline 1 & F18 & 137.34 & 0.151 & 0.217 & 0.063 & 0.960 & 45.78 & 7.76 & 7.06 & 7.03 & 7.01 & 7.01 & Kachcha \\
\hline 2 & F15 & 26.77 & 0.029 & 0.022 & 0.009 & 0.960 & 8.92 & 7.26 & 6.17 & 6.23 & 6.18 & 6.17 & Kachcha \\
\hline 3 & F12 & 126.36 & 0.139 & 0.087 & 0.039 & 0.960 & 42.12 & 7.74 & 7.01 & 6.99 & 6.96 & 6.96 & Kachcha \\
\hline 4 & F13 & 69.07 & 0.076 & 0.022 & 0.017 & 0.960 & 23.02 & 7.55 & 6.69 & 6.70 & 6.66 & 6.66 & Kachcha \\
\hline 5 & F25 & 59.55 & 0.066 & 0.022 & 0.015 & 0.960 & 19.85 & 7.51 & 6.61 & 6.62 & 6.59 & 6.59 & Kachcha \\
\hline 6 & F14 & 156.56 & 0.172 & 0.217 & 0.066 & 0.960 & 52.19 & 7.80 & 7.13 & 7.09 & 7.07 & 7.07 & Kachcha \\
\hline 7 & F19 & 131.38 & 0.145 & 0.130 & 0.047 & 0.960 & 43.79 & 7.75 & 7.03 & 7.01 & 6.98 & 6.98 & Kachcha \\
\hline 8 & F17 & 160.76 & 0.177 & 0.152 & 0.056 & 0.960 & 53.59 & 7.81 & 7.14 & 7.11 & 7.09 & 7.09 & Kachcha \\
\hline 9 & $\mathrm{~F} 21$ & 40.87 & 0.045 & 0.130 & 0.030 & 0.960 & 13.62 & 7.39 & 6.40 & 6.44 & 6.40 & 6.40 & Kachcha \\
\hline 10 & F31 & 42.32 & 0.025 & 0.063 & 0.010 & 1.431 & 14.11 & 7.40 & 6.42 & 6.46 & 6.41 & 6.41 & Mainland \\
\hline 11 & F23 & 128.57 & 0.077 & 0.031 & 0.013 & 1.431 & 42.86 & 7.74 & 7.02 & 7.00 & 6.97 & 6.97 & Mainland \\
\hline 12 & $\mathrm{~F} 24$ & 157.30 & 0.094 & 0.125 & 0.026 & 1.431 & 52.43 & 7.80 & 7.13 & 7.10 & 7.07 & 7.07 & Mainland \\
\hline 13 & F33 & 252.93 & 0.151 & 0.031 & 0.021 & 1.431 & 84.31 & 7.95 & 7.39 & 7.33 & 7.31 & 7.31 & Mainland \\
\hline 14 & F34 & 287.60 & 0.171 & 0.125 & 0.035 & 1.431 & 95.87 & 7.99 & 7.46 & 7.39 & 7.38 & 7.38 & Mainland \\
\hline 15 & F32 & 37.35 & 0.022 & 0.031 & 0.006 & 1.431 & 12.45 & 7.37 & 6.35 & 6.40 & 6.35 & 6.35 & Mainland \\
\hline 16 & F35 & 175.32 & 0.104 & 0.063 & 0.020 & 1.431 & 58.44 & 7.84 & 7.19 & 7.15 & 7.13 & 7.13 & Mainland \\
\hline 17 & F41 & 27.61 & 0.016 & 0.031 & 0.006 & 1.431 & 9.20 & 7.27 & 6.19 & 6.25 & 6.20 & 6.19 & Mainland \\
\hline 18 & F37 & 96.48 & 0.057 & 0.031 & 0.010 & 1.431 & 32.16 & 7.65 & 6.87 & 6.86 & 6.83 & 6.83 & Mainland \\
\hline 19 & F38 & 59.15 & 0.035 & 0.031 & 0.008 & 1.431 & 19.72 & 7.51 & 6.60 & 6.62 & 6.58 & 6.58 & Mainland \\
\hline 20 & F46 & 104.27 & 0.062 & 0.063 & 0.015 & 1.431 & 34.76 & 7.68 & 6.91 & 6.90 & 6.87 & 6.87 & Mainland \\
\hline 21 & F43 & 41.82 & 0.025 & 0.031 & 0.007 & 1.431 & 13.94 & 7.40 & 6.41 & 6.45 & 6.41 & 6.41 & Mainland \\
\hline 22 & F26 & 59.37 & 0.035 & 0.063 & 0.012 & 1.431 & 19.79 & 7.51 & 6.60 & 6.62 & 6.58 & 6.58 & Mainland \\
\hline 23 & F48 & 60.41 & 0.036 & 0.031 & 0.008 & 1.431 & 20.14 & 7.51 & 6.61 & 6.63 & 6.59 & 6.59 & Mainland \\
\hline 24 & F49 & 46.27 & 0.028 & 0.031 & 0.007 & 1.431 & 15.42 & 7.43 & 6.47 & 6.50 & 6.46 & 6.46 & Mainland \\
\hline 25 & F45 & 25.21 & 0.015 & 0.125 & 0.017 & 1.431 & 8.40 & 7.25 & 6.14 & 6.21 & 6.15 & 6.14 & Mainland \\
\hline 26 & F42 & 37.51 & 0.022 & 0.063 & 0.010 & 1.431 & 12.50 & 7.37 & 6.36 & 6.40 & 6.35 & 6.35 & Mainland \\
\hline 27 & $\mathrm{~F} 2$ & 201.45 & 0.116 & 0.087 & 0.016 & 1.478 & 67.15 & 7.88 & 7.26 & 7.22 & 7.20 & 7.20 & Saurashtra \\
\hline 28 & F10 & 218.77 & 0.126 & 0.043 & 0.013 & 1.478 & 72.92 & 7.90 & 7.31 & 7.26 & 7.24 & 7.24 & Saurashtra \\
\hline 29 & F7 & 138.75 & 0.080 & 0.043 & 0.009 & 1.478 & 46.25 & 7.76 & 7.06 & 7.03 & 7.01 & 7.01 & Saurashtra \\
\hline 30 & F8 & 142.65 & 0.082 & 0.087 & 0.013 & 1.478 & 47.55 & 7.77 & 7.08 & 7.05 & 7.03 & 7.03 & Saurashtra \\
\hline 31 & F9 & 154.00 & 0.089 & 0.043 & 0.010 & 1.478 & 51.33 & 7.80 & 7.12 & 7.09 & 7.06 & 7.06 & Saurashtra \\
\hline 32 & F28 & 23.19 & 0.013 & 0.174 & 0.014 & 1.478 & 7.73 & 7.22 & 6.10 & 6.16 & 6.11 & 6.10 & Saurashtra \\
\hline 33 & F30 & 15.58 & 0.009 & 0.087 & 0.007 & 1.478 & 5.19 & 7.10 & 5.88 & 5.97 & 5.91 & 5.88 & Saurashtra \\
\hline 34 & F5 & 287.42 & 0.166 & 0.043 & 0.016 & 1.478 & 95.81 & 7.99 & 7.46 & 7.39 & 7.38 & 7.38 & Saurashtra \\
\hline 35 & F11 & 169.44 & 0.098 & 0.087 & 0.014 & 1.478 & 56.48 & 7.83 & 7.17 & 7.13 & 7.11 & 7.11 & Saurashtra \\
\hline 36 & $\mathrm{~F} 1$ & 58.52 & 0.034 & 0.043 & 0.006 & 1.478 & 19.51 & 7.50 & 6.60 & 6.62 & 6.58 & 6.58 & Saurashtra \\
\hline 37 & F3 & 118.89 & 0.069 & 0.087 & 0.012 & 1.478 & 39.63 & 7.72 & 6.98 & 6.96 & 6.93 & 6.93 & Saurashtra \\
\hline 38 & F29 & 54.22 & 0.031 & 0.087 & 0.009 & 1.478 & 18.07 & 7.48 & 6.55 & 6.58 & 6.54 & 6.54 & Saurashtra \\
\hline 39 & $\mathrm{~F} 4$ & 92.34 & 0.053 & 0.043 & 0.007 & 1.478 & 30.78 & 7.64 & 6.84 & 6.84 & 6.81 & 6.81 & Saurashtra \\
\hline 40 & F6 & 56.39 & 0.033 & 0.043 & 0.006 & 1.478 & 18.80 & 7.49 & 6.58 & 6.60 & 6.56 & 6.56 & Saurashtra \\
\hline
\end{tabular}

Abbreviation: Wells and Coppersmith (1994) - W\&C (1994).

each seismic zone. In this regard, there are two alternatives to choose from. One is the maximum historical earthquake procedure. In the standard rule-of-thumb practice, the maximum historical earthquake is increased by half a magnitude unit or, through a recurrence relationship, is taken to yield the maximum magnitude (Nuttli, 1979). Nevertheless, this alternative is not applicable to all seismic source zones determined in this study for the reasons: (a) all the faults mapped or determined as "active" in present study did not show any predominant activity during the past history; (b) those showing the seismic activity are very poorly known and far away from providing a reliable maximum magnitude earthquake determination because of uncertainties attributed to both instrumental and historical records; (c) the accurate amount of slip and slip rate or the fault rupture could not be obtained due to lack of historic instrumentations.

The second methodology for the determination of maximum magnitude earthquake for a seismic source zone is from the empirical correlations between key fault parameters (Fault Rupture length, fault displacement and fault area). In this regard, the most common feature is the fault rupture length and it is presently used in the determination of maximum magnitude associated with a particular fault. There are different opinions on the rupture length of faults to yield the maximum magnitude earthquake. The general assumption based on worldwide data, is that $1 / 3$ to $1 / 2$ of the total length of the fault may rupture (Mark, 1977). The maximum magnitude is calculated using $1 / 3$ of the total fault length as 


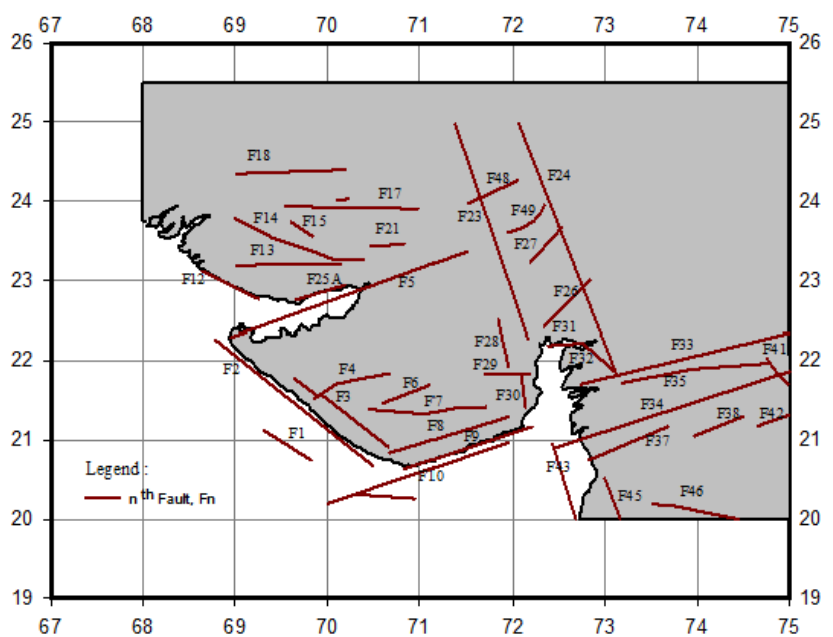

Fig. 5. The Fault map used in the present study.

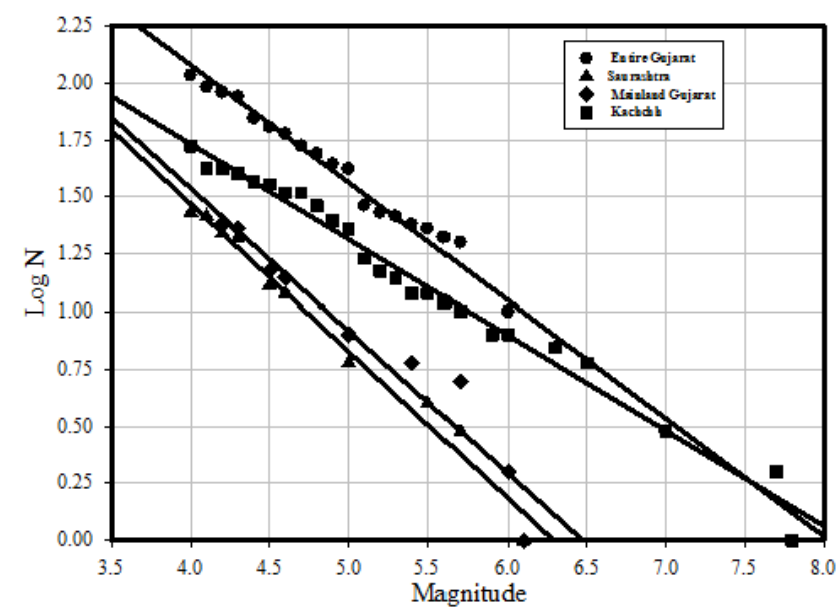

Fig. 6. Gutenberg-Richter frequency magnitude recurrence relationship for Kachchh, Saurashtra, Mainland regions and the entire region of Gujarat.

rupture length and using the relationship given by Bonilla et al. (1984), Nowroozi (1985), Slemmons et al. (1989) and Wells and Coppersmith (1984); the results are presented in Table 2. The minimum out of the estimated maximum magnitude is finally assigned to the particular fault as the maximum magnitude for seismic hazard calculations.

\section{Recurrence relations}

Using the prepared earthquake catalogue, the estimated Gutenberg-Richter (G-R) magnitude-frequency recurrence relationship for the three study areas is plotted in Fig. 6. In comparison to other studies on the seismic hazard for the Indian Peninsular shield (Table 3), the estimated $b$-value is low in the present study. There are large variations in the $b$-value reported by various researchers for peninsular India and the Gujarat region. It is very difficult to achieve agreement on one single value for the study. Tectonic earthquakes are characterized by the $b$-value from 0.5 to 1.5 and are more frequently around 1.0. In the present study, earthquakes less than $M_{\mathrm{w}}=4$ are not included. Eliminating the big class of the small earthquakes while fitting the Gutenberg-Richter (G-R) line may tend to flatten the line. As a result, the actual mean rate of small earthquakes will be underestimated and the mean rate of large earthquakes will be overestimated. A lower $b$-value for Kachchh region may be due to the predominance of a few big earthquakes in the region and a higher $b$-value for other region may be due to lack of significant numbers of big earthquakes. The uncertainty in the $b$-value is dealt with in the present study using the logic tree approach with the selection of corresponding $b$-value and its weightage. In the present analysis, two $b$-values are selected, i.e. one corresponds to the study area obtained using the present study and the second one using the regional $b$-value as reported by Jaiswal and Sinha (2007).

Furthermore, the occurrence of an earthquake in a seismic source is assumed to follow a Poisson's distribution. The probability of the ground motion parameter (horizontal component of peak ground acceleration in present study) at a given site, $Z$ to exceed a specified level, $z$, during a specified time, $T$, is represented by the expression:

$P(Z>z)=1-e^{-v(z) T} \leq v(z) T$

Where, $v(\mathrm{z})$ is the mean annual rate of exceedance of ground motion parameter, $\mathrm{Z}$ with respect to $\mathrm{z}$. Assuming that the $\mathrm{N}_{i}\left(\mathrm{~m}_{0}\right)$ is the frequency of an earthquake on seismic source $\mathrm{i}$, having a magnitude higher than a minimum magnitude of $\mathrm{m}_{0}$ (in present study it is taken as 4.0). The recurrence relation for each seismic source capable of producing an earthquake magnitude in the range of $m_{0}$ (minimum magnitude) to $\mathrm{m}_{\max }$ (maximum magnitude assigned) was calculated using the truncated exponential recurrence model (McGuire and Arabaz, 1990), given by the following expression

$N\left(m_{0}\right)=\frac{e^{-\beta\left(m-m_{0}\right)}-e^{-\beta\left(m_{\max }-m_{0}\right)}}{1-e^{-\beta\left(m_{\max }-m_{0}\right)}} \pi$
form $_{0} \leq m \leq m_{\max }$

Where $\beta=\log _{10}$ ( $b$-value) ( $b$-value is Gutenberg-Ritcher parameter, see Table 3 ).

\subsection{Fault recurrence relations}

The recurrence relation derived above (Eq. 2) is valid for the entire region and is not specific to any particular faults assumed in the study. Fault-level recurrence is necessary to discriminate nearby sources from far-off sources and to differentiate the activity rate among faults. In Gujarat, fault studies are not available presently and historical data are not sufficient to establish fault recurrence relations. In addition, PI (Peninsular India) earthquakes are associated with poor 
Table 3. Comparison of $b$-value for the Gujarat region to values reported by various researchers.

\begin{tabular}{cclll}
\hline $\begin{array}{c}\text { Study } \\
\text { number }\end{array}$ & $\begin{array}{c}\text { Application } \\
\text { area }\end{array}$ & $b$-value & Reference & $\begin{array}{l}\text { Periods for } \\
\text { study taken }\end{array}$ \\
\hline 1 & Kachchh & 0.417 & Present study & $\begin{array}{c}(1820-2008) \\
(1872-2008)\end{array}$ \\
2 & Saurashtra & 0.64 & & $(1872-2008)$ \\
3 & Mainland & 0.62 & & $(1820-2008)$ \\
4 & Entire Gujarat & 0.51 & & - \\
\hline 5 & Kachchh & 0.43 & Ashara et al. (2006) & - \\
6 & Gujarat & 0.72 & Tripathi et al. (2005) & - \\
7 & Peninsular & 0.47 & Gupta \& Rastogi (1976) & 70 yr \\
& India (PI) & & & $(1954-1967)$ \\
8 & & 0.81 & Avadh Ram and Rathor (1970) & $(1800-1983)$ \\
9 & & 0.7 & Kaila et al. (1972) & $(1842-2002)$ \\
10 & & 0.85 & Rao and Rao (1984) & $(1802-2002)$ \\
11 & & 0.92 & Jaiswal and Sinha (2007) & $(1507-2008)$ \\
13 & Mumbai & 0.86 & Raghu Kanth and Iyengar (2006) & $(1800-2004)$ \\
\hline 14 & Southern PI & 1.13 & Menon et al. (2010) & \\
\hline
\end{tabular}

Note: PI - Peninsular India

surface expression of faults and hence, reliable estimation of slip rates in order to model earthquake recurrence alternatively has also not been possible. In such situations, the $b$ value to the particular fault is empirically fixed considering the conservation of seismic activity in that particular region.

Followed by Iyengar and Ghosh (2004), Raghu Kanth and Iyengar (2006), Anbazhagan et al. (2009) and Vipin et al. (2009), the regional recurrence relations are scaled down to fault recurrence relations by introducing a weighting factor as given below:

$$
\begin{aligned}
& N_{i}\left(m_{0}\right)=F_{i}\left(m_{0}\right) \pi \frac{e^{-\beta\left(m-m_{0}\right)}-e^{-\beta\left(m_{\max }-m_{0}\right)}}{1-e^{-\beta\left(m_{\max }-m_{0}\right)}} \\
& \text { form }_{0} \leq m \leq m_{\max }
\end{aligned}
$$

In which $F_{i}\left(m_{0}\right)$ is the weighting factor as given below:

$$
F_{i}\left(m_{0}\right)=0.5\left(\alpha_{i}+x_{i}\right)
$$

Where $\alpha_{i}$ and $x_{i}$ are the weighting factors for length and earthquake event, respectively, which are given as below. Considering the fact that a longer fault can produce a greater number of small events of magnitude $\mathrm{m}_{0}$ than a shorter fault, fault recurrence may be taken as being proportional to the length of the fault, leading to a simple weight factor $\alpha_{i}$ as given below:

$\alpha_{i}=\frac{L_{i}}{\Sigma L_{i}}$

Where $L_{i}$ is the length of the fault $i$ and $\Sigma \mathrm{L}_{i}$ is the total fault length within the region under consideration. Further, the regional seismicity measured in terms of the number of earthquakes per year with $m \geq m_{0}$, should be equal to the sum of such events the sum of such events occurring on individual faults for particular area under consideration. It is also obvious that future activity will continue at seismic sources, at least in the short run, similar to past activity. Hence, irrespective of its length, seismic activity of a fault should be related to the number of past events associated with it in the catalogue and it is given by

$x_{i}=\frac{\text { Number of earthquakes close to the fault }}{\text { Total number of earthquakes in the region }}$

Since the Gujarat region is divided into three control regions, it would be appropriate to use the control region specific $b$ value for individual faults. The above argument provides a basis for decomposing the regional hazard into fault recurrence relations. The weight factors and obtained fault recurrence relation $\mathrm{N}_{i}\left(\mathrm{~m}_{0}\right)$ are presented in Table 2. Based on the calculated parameters from Table 2, Fig. 6 and above discussion, the fault recurrence relations using $b$-value calculated in present study and $b$-value reported by Jaiswal and Sinha (2007), are calculated and graphically presented in Fig. 7.

\section{Ground Motion Attenuation Relations (GMARs)}

Once the maximum magnitudes that each fault zone can generate are determined through the empirical relationship (Table 2), the next step is the selection of appropriate Ground Motion Attenuation Relation (GMAR) to estimate ground motion parameters at site. Raghu Kanth and Iyengar (2007) proposed an empirical GMAR for Peninsular India based on the stochastic seismological model and its comparison with instrumented data from the Koyna (1967) and Bhuj (2001) earthquakes. In order to try different forms of attenuation 

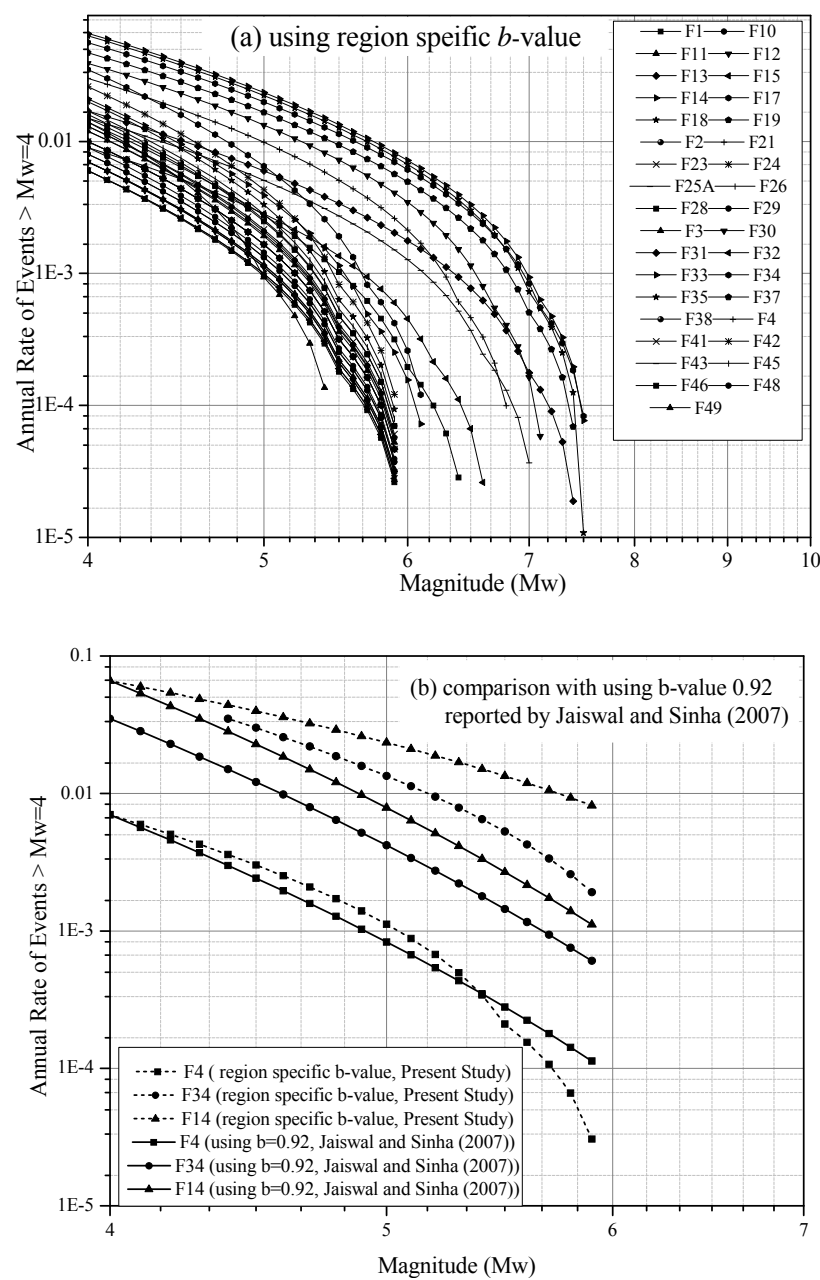

Fig. 7. Fault recurrence relations (a) using $b$-value calculated in present study (b) comparison with using $b$-value 0.92 reported by Jaiswal and Sinha (2007) for some selected faults.

relationships, several other approaches were also employed to have a chance for comparison. For shallow crustal earthquakes, GMAR proposed by Abrahamson and Silva (1997) is applicable and used in the present study. The comparison made by Petersen et al. (2004) has revealed that the crustal intraplate relation of Frankel et al. (1996) yields ground motions similar to the strong ground motion data recorded from the 2001 earthquake at large distances (Cramer and Wheeler, 2001). In the present study, we have also included the crustal intraplate GMARs given by Toro et al. (1997) and Frankel et al. (1996). The equations by Boore-Joyner-Fumal (1997), Campbell (1997) and Sadigh et al. (1997) representing the GMAR were also selected for comparison.

\section{Uncertainty in Seismic Hazard}

Epistemic uncertainties in the hazard computations have been accounted for within a logic-tree framework by con- sidering the following controlling parameters: (1) assigning region specific the $b$-value based on the present study and based on reported by researchers, (2) the maximum cutoff magnitude in hazard computations, and (3) the GMARs. Within the hazard analysis, assigned $b$-value maximum cutoff magnitudes and GMARs have been assigned different weights, which are presented in logic tree form in Fig. 8.

The $b$-value assigned in hazard computation is selected based on the present study and the value reported by Jaiswal and Sinha (2007) with equal weightage. Owing to the recent study made and the time period used in the study carried out, $b$-value $=0.92$ given by Jaiswal and Sinha (2007) has been selected for the hazard computations. There are significant variations in reported $b$-value (Table 3 ) and it is very difficult to assign different weightage for one over the other. Hence, equal weightage has been assigned to both the hazard computation framework, i.e. $b$-value calculated in present study and $b$-value $=0.92$. It may be noted that the variation in $b$ value obtained in the present study based on the study area of the Gujarat region only is due to the difference in study area as $b$-value reported by Jaiswal and Sinha (2007) was for the whole of Peninsular India.

In the present study, the maximum cutoff magnitude is calculated based on empirical correlation using key fault parameters (Fault length). As an alternative, each fault is assigned as the observed magnitude based on the past historic event within the nearby area. Equal weights have been assigned to the two different maximum magnitudes, as there is clearly no ground for choosing one alternative over the other. This is also in agreement that the present study is based on the fault map prepared, from which some of the faults may not be active and the maximum observed magnitude may give a reasonable idea about the current seismic activity in the region.

In order to compute the maximum horizontal ground acceleration for a given point assuming a hard rock site, various GMARs have been selected as shown in Fig. 8. Raghu Kanth and Iyengar $(2004,2007)$ have studied the attenuation of PGA and Spectral acceleration in Peninsular India from the considerations of engineering seismology and obtained the coefficients for attenuation equations from extensive seismological modeling and simulation. As this domestic GMAR given by Raghu Kanth and Iyengar (2007), is related specifically to Peninsular India, slightly higher weight (0.2) is assigned to it compared to other imported GMARs. However, it is notable that this relation is only valid for bedrock sites with a shear wave velocity of $3.6 \mathrm{~km} \mathrm{~s}$. Other GMARs used are for comparison and owing to the fact that it is difficult to assign a higher weight to one equation over the other, equal weights $(0.133)$ have been chosen for all imported GMARs. To avoid confusion associated with different magnitude scales, all magnitudes have been assumed to be moment magnitude $M_{\mathrm{w}}$ in entire study. 


$\begin{array}{lllll}\text { Region } & \text { Control } & \text { City } & b \text { - } & \text { Maximum } \\ & \text { Region } & & \text { value } & \text { Magnitude }\end{array}$

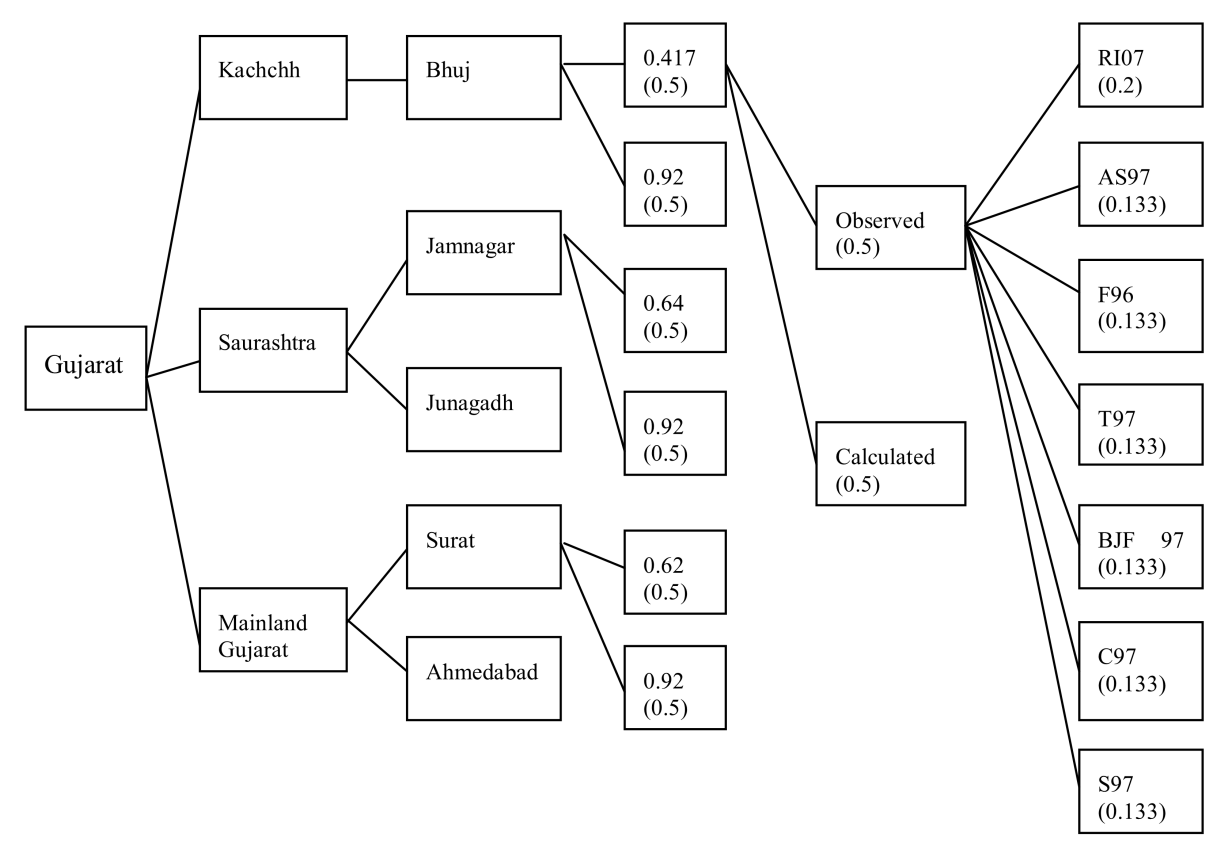

Fig. 8. Logic Tree used in seismic hazard computations (figures in the bracket show the weightage assigned in seismic hazard computations) (Abbreviations: Raghu Kanth and Iyengar (2007) - RI07, Abrahamson and Silva (1997) - AS97, Frankel (1996) - F96, Toro et al. (1997) T97, Boore-Joyner and Fumel (1997) - BJF97, Campbell (1997) - C97, Sadigh et al. (1997)- S97).

\section{Deterministic seismic hazard computation}

Seismic hazard analysis has been carried out using a deterministic approach. In the present deterministic hazard calculation, the seismic activity of seismic sources (fault sources) is specified by a recurrence relationship calculated, defining the cumulative number of events per year versus their magnitude. The distribution of earthquakes is assumed to be uniform within the source zone and independent of time (Cornell, 1968). Each Fault source is characterized by the seismicity parameters in terms of minimum and maximum magnitude and G-R earthquake recurrence rates as calculated in previous sections. Deterministic seismic hazard assessments carried out to identify maximum credible earthquake (MCE) and safe shutdown earthquake (SSE) that will affect a site. The shortest distance from vulnerable sources identified (Table 2) for the cities under consideration has been measured from the seismotectonic map. With these distances, maximum moment magnitude assigned and uncertainty as per the logic tree, using GMARs, the horizontal component of peak ground acceleration has been calculated at bed rock level by assuming a focal depth of the earthquake of about $10 \mathrm{~km}$ from the surface.
Assuming the maximum credible earthquake (MCE) is the earthquake which imposes the most severe kind of loading the structure ever likely experience (design life of structure i.e. $50 \mathrm{yr}$ ), the probability of this level of earthquake at the site is low. The deterministic analysis pertaining to the 50th percentile ground motion is thought to represent MCE in the present study. The Safe Shutdown Earthquake, on the other hand, is thought to represent the severest earthquake in terms of magnitude at the site. An earthquake of this magnitude may not have occurred in the past, but this value is arrived at after investigation of past earthquakes, local geology (fault structure, distance from the fault etc.), and local underlying soil characteristics. The 84th percentile deterministic ground motion calculated represents the SSE in the present study.

\section{Results and discussions}

\subsection{Deterministic scenarios and hazard computations}

Seed (1982) defined Maximum Credible Earthquake (MCE) as the largest conceivable event that could occur in the tectonic environment in which the site is located. Krinitzsky (2002) has pointed out that although Maximum 


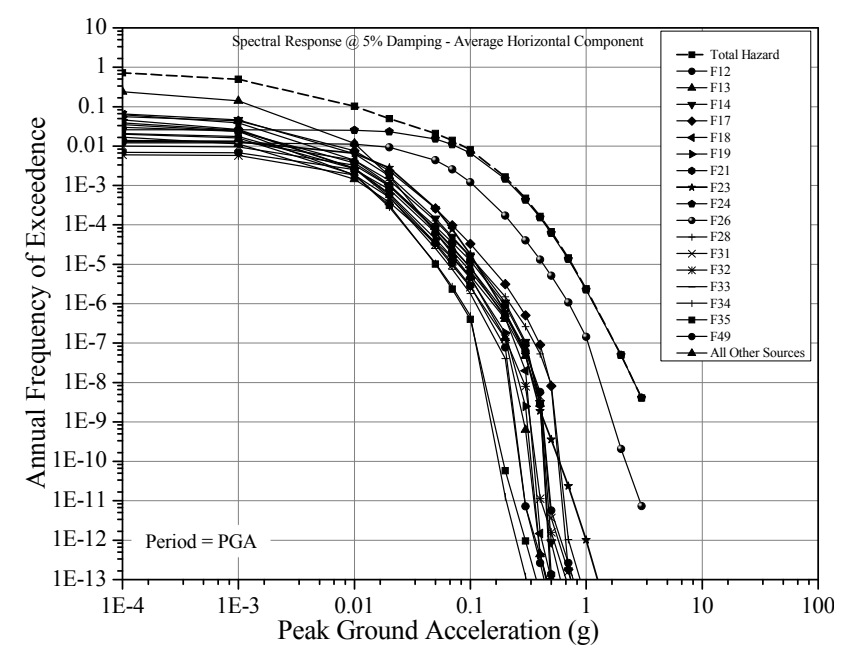

Fig. 9. Total hazard for the city of Ahmedabad obtained from the contribution of fault sources.

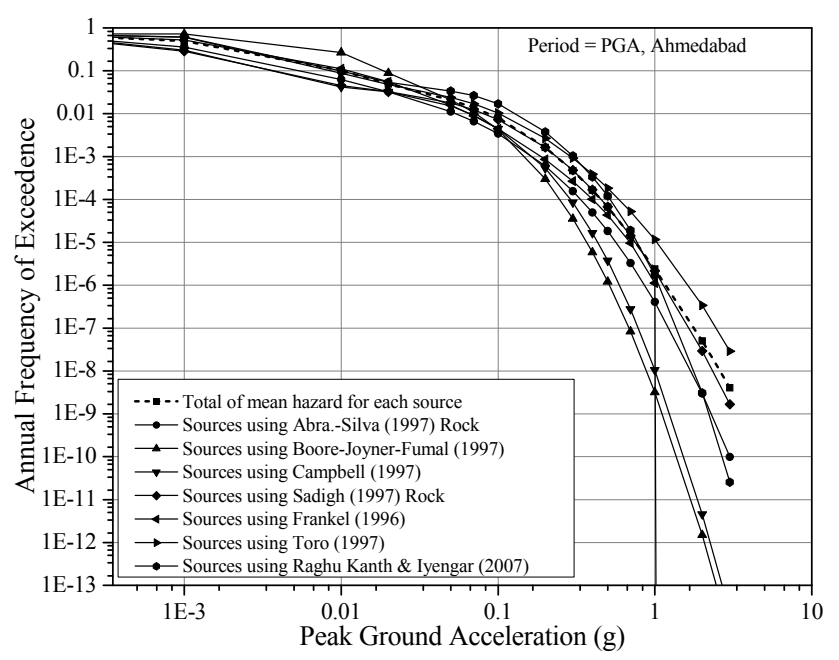

Fig. 10. Comparison of ground motion attenuation relations (GMARs) computed using various models for total hazard for the city of Ahmedabad.

Credible Earthquake (MCE) is the largest earthquake that can be reasonably expected to occur with in the design life of a structure (based on geological evidence and earthquake history), this does not necessarily imply that it would also be the worst. The maximum earthquake magnitude calculated and assigned earthquake to the faults as observed in the past history are also mentioned in Table 1 . From Table 4 it is easy to pick the MCE and SSE for each site considering the nearest fault producing the largest ground motions. From the deterministic analysis it is found that for the cities of Surat, Ahmedabad, Bhuj, Jamnagar and Junagadh, fault numbers F34, F24, F12, F5 and F7 are the controlling faults, respectively, owing to the shortest distance criteria. However in practice, structures are designed for ground motions, not earthquakes, so obtained deterministic scenario earthquakes should be obtained in the form of worst-case ground motion and not just a maximum magnitude-distance pair. In order to estimate reliable ground motions, a probabilistic framework is further used to compute the hazard contribution exceeding a certain level offered by each fault due to all possible future activities on the faults as visualized by the typical hazard scenario presented for Ahmedabad city in Fig. 9. From Fig. 9, it is clear that hazard contributions from fault numbers F26, F24 and F13 are maximum compared to the other faults for Ahmedabad city. In order to compare all the GMARs used in estimating the ground motions at site, a typical comparison for the city of Ahmedabad is presented in Fig. 10. From Fig. 10 it can be observed that the GMAR given by Campbell (1997) gives the highest hazard for Ahmedabad compared to all other GMARs used. However, all the GMARs are comparable and no significant variations in the estimated hazard have been observed as shown in Fig. 10.

The total hazard obtained from all the sources for a particular site is typically presented in Fig. 11. It is quite clear that out of the five cities studied, Bhuj has the highest hazard compared to all the others. Surat has higher hazard compared to Ahmedabad, being very close to the Narmada Son Lineaments. Although the hazard for the cities of Jamnagar and Junagadh are more or less the same, Jamnagar city has the lowest seismic hazard compared to all other cities. The finally-computed deterministic seismic scenarios for the cities are presented in terms of magnitude and distance pairs in Table 5. It is notable that these deterministic scenarios are not fact or do not belong to any particular fault, but ground motion computed using these scenarios can produce the same level of ground motion which can be expected at a given site.

\subsection{Development of deterministic hazard spectra}

As expressed earlier, in practice design engineers are generally more interested in specifying the ground motions in terms of PGA or in terms of spectra as specified by provisions made by code. In deterministic analysis for a given probability of exceedance, the probability distribution for the hazard value can be determined from which the specified fractiles (usually 50th percentile i.e. median and 84th percentile) are computed. However, the deterministic ground motions should not just be called the median and 84th percentile ground motions but rather they should be called the ground motions with $50 \%$ chance and $84 \%$ chance of not being exceeded for the design earthquake (the 84th percentile deterministic ground motion has a $16 \%$ chance of being exceeded if the scenario earthquake occurs). In the present analysis, 50th percentile (representing MCE) and 84th percentile (representing SSE) deterministic spectra for spectral response for $5 \%$ damping at the bed rock level, have been developed varying $b$-value as given in logic tree. The $5 \%$ 
Table 4. Deterministic scenarios for various cities under consideration in the present study.

\begin{tabular}{|c|c|c|c|c|c|c|c|}
\hline \multirow[t]{2}{*}{$\begin{array}{l}\text { Name of } \\
\text { fault }\end{array}$} & \multirow[t]{2}{*}{$\begin{array}{l}\text { Maximum } \\
\text { Magnitude } \\
\text { (Calculated) }\end{array}$} & \multirow[t]{2}{*}{$\begin{array}{l}\text { Maximum } \\
\text { Magnitude } \\
\text { (Observed) }\end{array}$} & $\begin{array}{l}\text { Surat } \\
\text { City }\end{array}$ & $\begin{array}{l}\text { Ahmedabad } \\
\text { City }\end{array}$ & $\begin{array}{l}\text { Bhuj } \\
\text { City }\end{array}$ & $\begin{array}{l}\text { Jamnagar } \\
\text { City }\end{array}$ & $\begin{array}{l}\text { Junagadh } \\
\text { City }\end{array}$ \\
\hline & & & \multicolumn{5}{|c|}{ Hypocentral Distance $(\mathrm{km}), h=10 \mathrm{~km}$} \\
\hline $\mathrm{F} 1$ & 6.58 & 5.5 & 315.63 & 381.32 & 231.23 & 169.01 & 107.63 \\
\hline F10 & 7.24 & 5.5 & 93.67 & 238.18 & 231.23 & 225.62 & 231.23 \\
\hline F11 & 7.11 & 5 & 118.57 & 279.47 & 320.36 & 239.02 & 133.93 \\
\hline F12 & 6.96 & 6.66 & 357.46 & 249.08 & 6.22 & 84.05 & 191.24 \\
\hline F13 & 6.66 & 6.96 & 336.68 & 245.07 & 35.56 & 48.23 & 158.72 \\
\hline F14 & 7.07 & 7.07 & 342.65 & 225.42 & 23.37 & 89.93 & 194.18 \\
\hline F15 & 6.17 & 6.17 & 407.04 & 286.03 & 45.51 & 126.3 & 236.5 \\
\hline F17 & 7.09 & 7.09 & 359.46 & 189.8 & 86.8 & 164 & 267.69 \\
\hline F18 & 7.01 & 7.01 & 416.47 & 264.78 & 98.43 & 173.81 & 280.67 \\
\hline F19 & 6.98 & 6.98 & 450.28 & 286.78 & 137 & 216.08 & 322.31 \\
\hline $\mathrm{F} 2$ & 7.2 & 5.5 & 248.25 & 337 & 144.18 & 110.97 & 62.91 \\
\hline $\mathrm{F} 21$ & 6.4 & 6.4 & 328.27 & 184.95 & 73.96 & 115.21 & 213.84 \\
\hline F23 & 6.97 & 5.5 & 142.3 & 63.02 & 206.85 & 198.34 & 195.09 \\
\hline F24 & 7.07 & 5.5 & 81.57 & 14.11 & 279.7 & 274.83 & 272.97 \\
\hline $\mathrm{F} 25 \mathrm{~A}$ & 6.59 & 6.59 & 336.68 & 245.07 & 35.56 & 48.23 & 158.72 \\
\hline F26 & 6.58 & 5.5 & 149.1 & 22.42 & 270.99 & 228.35 & 217.82 \\
\hline F28 & 6.1 & 6 & 125.43 & 96.05 & 219.95 & 177.66 & 160.79 \\
\hline F29 & 6.54 & 5.5 & 101.47 & 138.83 & 242.29 & 176.47 & 131.87 \\
\hline F3 & 6.93 & 5.5 & 227.14 & 306.38 & 153.06 & 88.82 & 32.75 \\
\hline F30 & 5.88 & 5.5 & 77.37 & 142.09 & 275.58 & 214.54 & 170.89 \\
\hline F31 & 6.41 & 5.5 & 118.08 & 91.33 & 284.48 & 235.29 & 212.1 \\
\hline F32 & 6.35 & 5.5 & 84.22 & 93.7 & 321.18 & 274.8 & 250.49 \\
\hline F33 & 7.31 & 5.7 & 61.57 & 145.22 & 340.64 & 282.66 & 236 \\
\hline F34 & 7.38 & 5.7 & 11.59 & 213.35 & 369.19 & 296.41 & 216.51 \\
\hline F35 & 7.13 & 5.5 & 72.36 & 157.9 & 380.96 & 326.48 & 282.18 \\
\hline F37 & 6.83 & 5.5 & 39.99 & 235.66 & 409.59 & 338.23 & 259.25 \\
\hline F38 & 6.58 & 5.5 & 118.57 & 262.32 & 487.65 & 427.58 & 366.92 \\
\hline F4 & 6.81 & 5.5 & 235.63 & 236.49 & 162.32 & 79.07 & 31.15 \\
\hline F41 & 6.19 & 5.5 & 221.3 & 249.15 & 522.38 & 480.08 & 447.11 \\
\hline F42 & 6.35 & 5.5 & 189.26 & 296.67 & 544.85 & 489.96 & 436 \\
\hline F43 & 6.41 & 5.5 & 47.87 & 232.04 & 364.41 & 292.05 & 213.45 \\
\hline F45 & 6.14 & 5.5 & 73.4 & 282.56 & 439.96 & 367.59 & 285.13 \\
\hline F46 & 6.87 & 5.5 & 128.97 & 330.03 & 504.45 & 432.64 & 349.31 \\
\hline F48 & 6.59 & 5.5 & 340.68 & 145.66 & 196.41 & 222.02 & 294.46 \\
\hline F49 & 6.46 & 5.5 & 286.96 & 85.79 & 223.6 & 227.49 & 278.52 \\
\hline F5 & 7.38 & 5 & 280.64 & 115.91 & 49.68 & 33.97 & 143.98 \\
\hline F6 & 6.56 & 5.5 & 188.44 & 212.61 & 203.94 & 120.55 & 15.52 \\
\hline F7 & 7.01 & 5.5 & 120.31 & 200.5 & 206.86 & 123.33 & 13.6 \\
\hline F8 & 7.03 & 5 & 92.55 & 203.69 & 271.84 & 188.16 & 77.68 \\
\hline F9 & 7.06 & 5 & 64.74 & 210.5 & 298.37 & 214.71 & 104.4 \\
\hline
\end{tabular}

damping is specifically selected to compare the results of the present study with the provisions made in IS:1893- Part I (2002). The comparison of the obtained spectra for $b$ value obtained from the present study and $b$-value reported by Jaiswal and Sinha (2007), are presented in Fig. 12. The comparisons confirm that the higher ground motions are produced for the $b$-value $=0.92$ whereas spectra corresponds to the $b$-value from the present study gives comparatively lesser ground motions. The difference is very less for Bhuj city and observed to be highest for Ahmedabad city compared to all other cities studied. A significant difference is observed in the PGA value obtained by both the $b$-value approach. The calculated ground motions in terms of the horizontal component for spectral response at $5 \%$ damping for the few periods are tabulated in Table 6.

The cities of Junagadh and Jamnagar belong to the same tectonic control region, i.e. Saurashtra but the expected seismic ground motion for both of them is different, i.e. for 


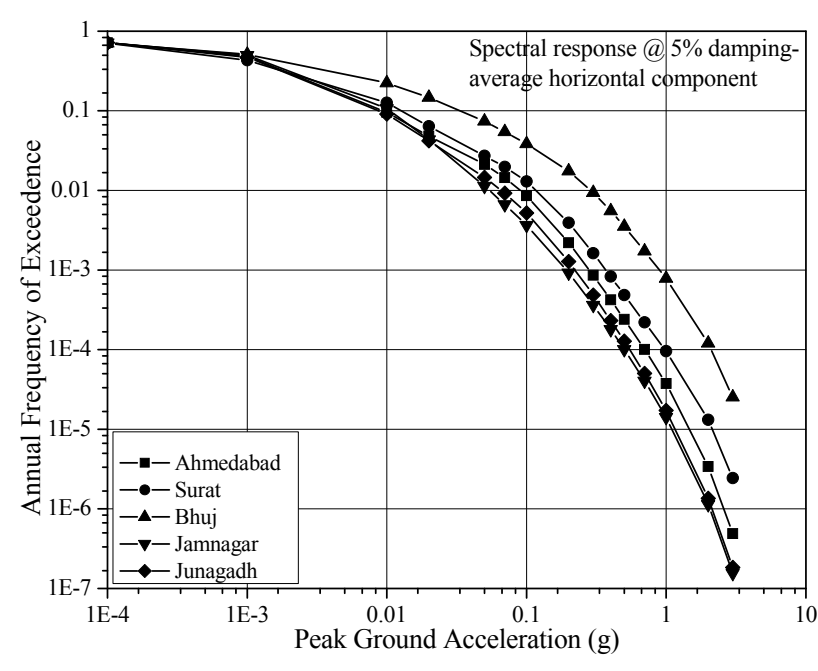

Fig. 11. Total Hazard calculated for various cities at zero spectral period i.e. PGA.

Junagadh being higher than Jamnagar. This is also consistent with recent activities as described by Yadav et al. (2010) in the Talala region very close to Junagadh. In the same way, Surat and Ahmedabad cities are sharing same tectonic control region as per the present study, but the calculated PGA for Surat city is slightly higher than for Ahmedabad. This is possibly due to the proximity of Surat city to the Narmada Son lineaments, considered to be a controlling fault for the city of Surat.

It is interesting to note that for the Bhuj region, the estimated PGA are in order of 0.64 to $1.04 \mathrm{~g}$ corresponding to $b$-value studied. Parvez et al. (2003) and Hough et al. (2002) has predicted near field ground motion of approximately $0.8 \mathrm{~g}$ for the Kachchh areas for the Bhuj 2001 earthquake which compared well with our present results. During the recent excavations at Bet Dwarka, in the Gulf of Kachchh, Rajendran et al. (2003) identified a seismically generated sand blow that has disrupted an ancient cultural horizon. The age data suggested that the causative earthquake may have occurred about 2000 years ago. While the source of this earthquake remains constrained, its timing seems to be singular; studies elsewhere in Kachchh have not disclosed any feature of a comparable age as yet. Their study opens the possibility for another surprise source, and may be adding a new dimension to the seismic hazard of the entire Gujarat region.

\subsection{Comparison with IS: 1893 - Part I (2002) spectra}

Several researchers had carried out studies on seismic zoning of India even before the publication of the first zoning map by the Bureau of Indian Standards in 1962. The early seismic maps were qualitative in nature and demarcated the areas of severe, moderate, light etc. damages (Krishna, 1959). The later studies quantified the seismic zones on the basis of
Modified Mercalli Intensity levels, similar to the IS code zoning (Guha, 1962). Updating has been marginally done only after the occurrence of large and damaging earthquakes (e.g., $M_{\mathrm{w}}=6.3$ Koyna; $\left.M_{\mathrm{w}}=7.7 \mathrm{Bhuj}, 2001\right)$. It is observed that the zoning prescribes a lower hazard for the regions without significant records of historical earthquakes and revisiting after the occurrence of damaging earthquakes. In addition, this map does not portray the seismic hazard at different locations and suffers from the weakness of assessing the return periods of postulated design seismic coefficients for various zones. Large magnitude earthquake may be expected in the region where not many earthquakes have occurred and seismic hazard at a site is controlled by all earthquakes expected to occur (including future) during the life of a structure in the area surrounding the site, and not only by the largest magnitude earthquake. In this paper, a comparison has been made between the compared spectra obtained in the present study with the IS: 1893-Part I (2002)-specified spectra for the cities studied. The PGA specified by IS:1893-Part I (2002) is compared with the obtained PGA value for the 50th percentile and 84th percentile as shown in Fig. 13.

The estimated PGAs for the cities of Ahmedabad and Surat are in agreement with that specified by IS:1893-Part I (2002) i.e. for Ahmedabad and Surat $0.13 \mathrm{~g}$ and $0.15 \mathrm{~g}$ respectively whereas the specified PGA is $0.16 \mathrm{~g}$. Though the estimated PGAs are at bed rock level, site specific corrections are required to be done for exact comparison. For Bhuj city, the estimated PGA $(0.64 \mathrm{~g})$ are high compared to $0.36 \mathrm{~g}$ specified by IS:1893-Part I (2002). As expressed earlier by Parvez et al. (2003) and Hough et al. (2002), the predicted near- field ground motion of approximately $0.8 \mathrm{~g}$ for the Kachchh areas for the Bhuj 2001 earthquake also shows that the estimated PGAs are higher than the IS:1893-Part I (2002). Being in zone III, IS:1893-Part I (2002), specifies that the expected PGA for Jamnagar city is in order of $0.24 \mathrm{~g}$ whereas the observed PGA as per the present study is around $0.16 \mathrm{~g}$. The PGA around Jamnagar city is also observed in the order of 0.18 to $0.2 \mathrm{~g}$ as per the seismic hazard map compiled by the Jaiswal and Sinha (2007). This shows that presently, the specified hazard is higher (30\% approximately) than the required as per the present study. Similarly, for the city of Junagadh, the specified PGA is of the $0.16 \mathrm{~g}$ level whereas in the present study it is observed of the order of $0.2 \mathrm{~g}$, higher than that specified by the IS:1893-Part I (2002) code. Jaiswal and Sinha (2007) have also shown that the seismic hazard in the region around Junagadh city is of the order of 0.12 to $0.18 \mathrm{~g}$ for the return period of $475 \mathrm{yr}$. The recent earthquake activities around Talala as described by Yadav et al. (2010) also indicate that the Junagadh region presently has a higher seismic hazard and when estimating future earthquakes, the level of PGA may be higher than that specified by code and should be increased without waiting for a big event to occur via a surprising source. 
Table 5. Deterministic magnitude-distance pair for hazard-producing ground motion exceeding $0.2 \mathrm{~g}$.

\begin{tabular}{lllll}
\hline City & Model & $\begin{array}{l}\text { Hazard (producing } \\
\text { ground motion } \\
\text { exceeding } 0.2 \mathrm{~g})\end{array}$ & $\begin{array}{l}\text { Mean magnitude } \\
\left(M_{\mathrm{W}}\right)\end{array}$ & $\begin{array}{l}\text { Distance } \\
(\mathrm{km})\end{array}$ \\
\hline Ahmedabad & $b$-value (present study) & 0.00164 & 5.11 & 15.88 \\
& $b$-value $=0.92$ & 0.00152 & 5.29 & 15.70 \\
\hline Surat & $b$-value (present study) & 0.00356 & 5.05 & 11.81 \\
& $b$-value $=0.92$ & 0.00293 & 5.04 & 12.45 \\
\hline Bhuj & $b$-value (present study) & 0.02230 & 5.52 & 12.56 \\
& $b$-value $=0.92$ & 0.01240 & 4.81 & 8.33 \\
\hline Jamnagar & $b$-value (present study) & 0.00069 & 6.57 & 69.27 \\
& $b$-value $=0.92$ & 0.000173 & 6.17 & 51.83 \\
\hline Junagadh & $b$-value (present study) & 0.00075 & 5.04 & 22.87 \\
& $b$-value $=0.92$ & 0.00088 & 5.33 & 18.89 \\
\hline
\end{tabular}

Table 6. Deterministic seismic 1 spectral ordinates for few reference periods.

\begin{tabular}{|c|c|c|c|c|c|c|}
\hline \multirow[t]{2}{*}{ Location } & \multirow[t]{2}{*}{$b$-value } & \multirow{2}{*}{$\begin{array}{l}\text { Deterministic } \\
\text { Percentile }\end{array}$} & \multicolumn{4}{|c|}{ Period (s) } \\
\hline & & & PGA & 0.20 & 0.50 & 1.00 \\
\hline \multirow{6}{*}{ 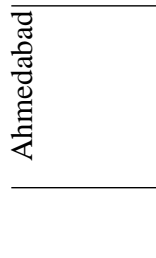 } & $0.62 *$ & (50-percentile) & 0.13 & 0.22 & 0.09 & 0.04 \\
\hline & $0.92 \#$ & & 0.48 & 0.86 & 0.58 & 0.36 \\
\hline & $0.62 *$ & (84-percentile) & 0.23 & 0.39 & 0.17 & 0.07 \\
\hline & 0.92 & & 0.78 & 1.41 & 0.96 & 0.58 \\
\hline & $0.62 *$ & (50-percentile) & 0.15 & 0.26 & 0.11 & 0.04 \\
\hline & 0.92 & & 0.35 & 0.61 & 0.35 & 0.18 \\
\hline \multirow{4}{*}{$\begin{array}{l}\overrightarrow{\mathbb{E}} \\
\tilde{\Xi}\end{array}$} & $0.62 *$ & (84-percentile) & 0.26 & 0.45 & 0.20 & 0.08 \\
\hline & 0.92 & & 0.57 & 1.02 & 0.59 & 0.31 \\
\hline & $0.417 *$ & (50-percentile) & 0.64 & 1.09 & 0.61 & 0.31 \\
\hline & 0.92 & & 0.75 & 1.46 & 1.02 & 0.61 \\
\hline \multirow{2}{*}{$\bar{\Xi}$} & $0.417 *$ & (84-percentile) & 1.08 & 1.85 & 1.04 & 0.54 \\
\hline & 0.92 & & 1.26 & 2.44 & 1.69 & 1.00 \\
\hline \multirow{4}{*}{ 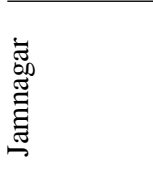 } & $0.64 *$ & (50-percentile) & 0.14 & 0.26 & 0.18 & 0.11 \\
\hline & 0.92 & & 0.27 & 0.52 & 0.40 & 0.28 \\
\hline & $0.64 *$ & (84-percentile) & 0.24 & 0.45 & 0.31 & 0.19 \\
\hline & 0.92 & & 0.45 & 0.88 & 0.66 & 0.46 \\
\hline \multirow{4}{*}{ 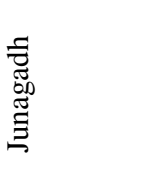 } & $0.64 *$ & (50-percentile) & 0.20 & 0.34 & 0.17 & 0.08 \\
\hline & 0.92 & & 0.45 & 0.81 & 0.54 & 0.33 \\
\hline & $0.64 *$ & (84-percentile) & 0.34 & 0.59 & 0.30 & 0.14 \\
\hline & 0.92 & & 0.73 & 1.32 & 0.89 & 0.53 \\
\hline
\end{tabular}

Note: *present study, ${ }^{\#}$ adopted from Jaiswal and Sinha (2007). 

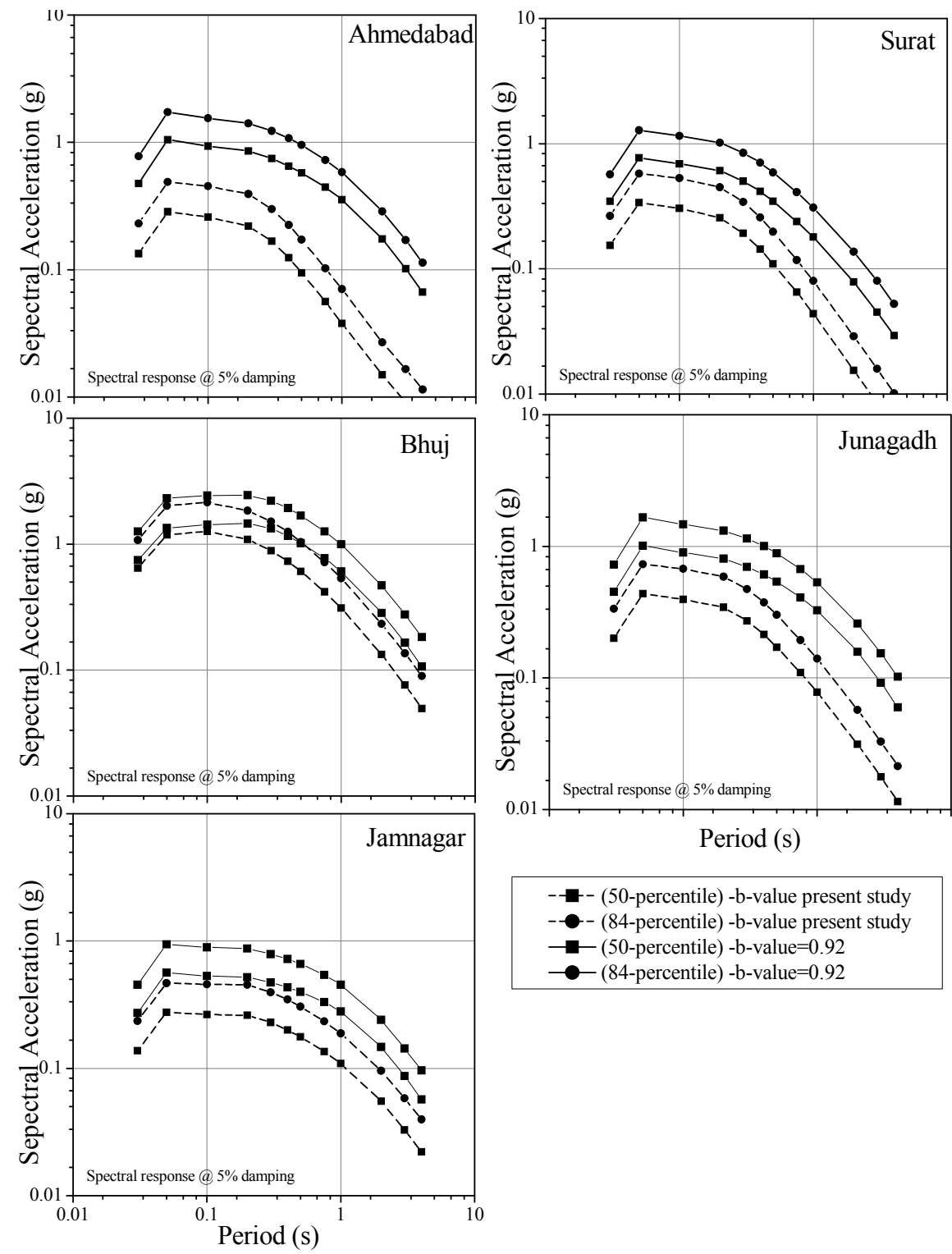

Fig. 12. Deterministic spectra obtained for various cities with different $b$-values. The ground accelerations are plotted in unit of $5 \%$ damped acceleration response spectrum as a function of period for different $b$-values at particular site location.

\section{Conclusions}

In order to be consistent with the other seismic codes worldwide and to cater to performance based seismic design approaches, it is necessary to develop regional seismic hazard maps/scenarios consistent with the local seismotectonic setting. The present study is the first step towards developing a state-of-the-art seismic hazard map for one of the most active regions of Peninsular India and forms a sound basis for future extension of the site-specific studies of the controlling regions. To estimate seismic ground motions for the few commercial hubs of the state of Gujarat, India, the determin- istic seismic hazard analysis is carried out using maximum magnitude earthquake associated with 40 faults. For each city, the hazard associated with each source is calculated using the classical Cornell approach, using the seven different GMARs including the domestic relations of India given by Raghu Kanth and Iyengar (2007). The deterministic spectra obtained using the 50th percentile (representing MCE) and 84th percentile (representing SSE) have been developed using the probabilistic framework and logic tree approach and compared with the IS:1893-Part I (2002) specified spectra. The seismic hazard in the Gujarat region is quite scattered. It is much higher for the Kachchh region (i.e. Bhuj city) and 


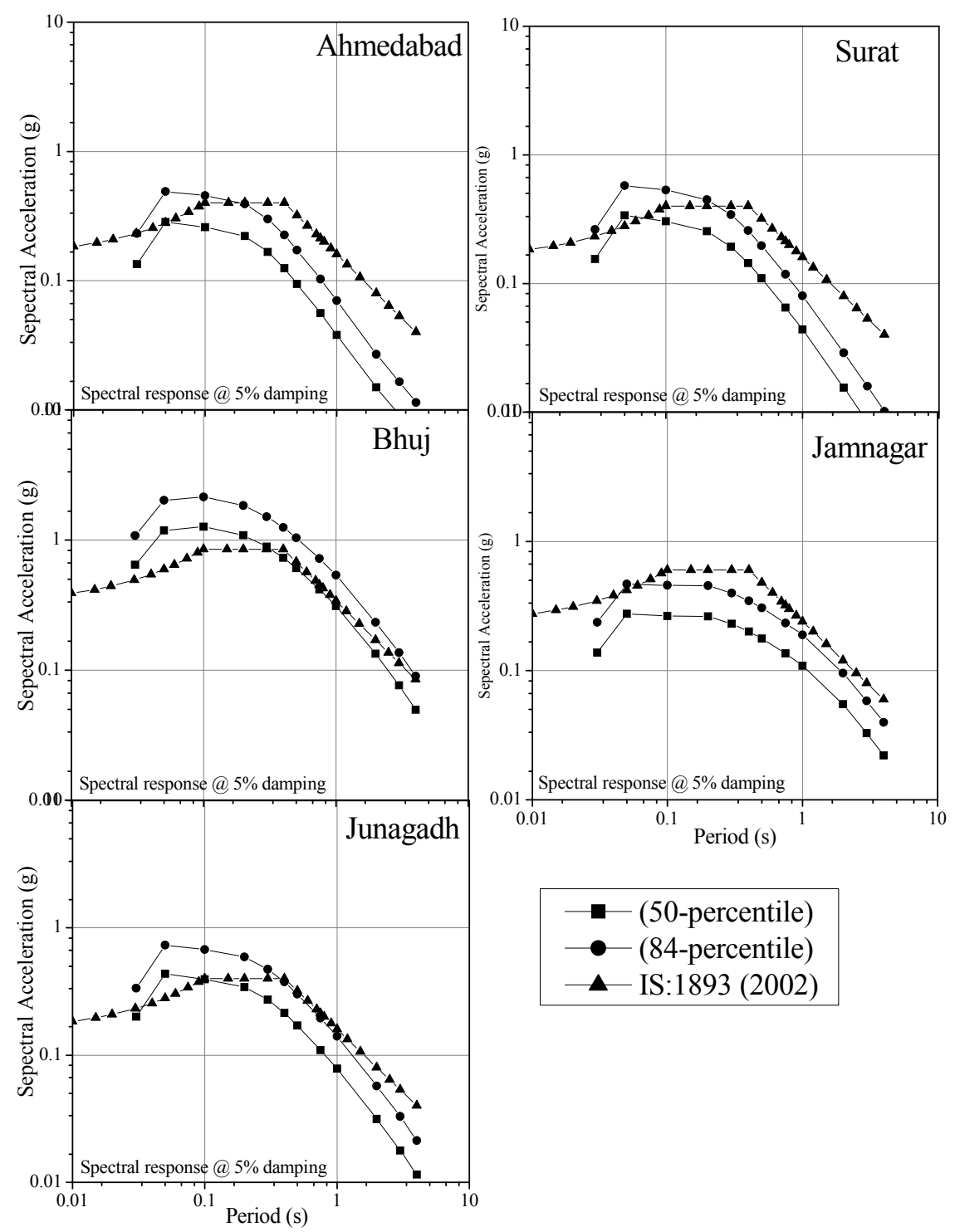

Fig. 13. 50th percentile deterministic hazard spectra for five cities in Gujarat, India. The ground accelerations are plotted in unit of $5 \%$ damped acceleration response spectrum as a function of period and its comparison with IS:1893-Part I (2002) specified spectra for seismic design of structures at particular site location.

comparatively lower for the Saurashtra and Mainland regions of Gujarat State. The most vulnerable site is Bhuj city as it is very close to the most active faults in the state of Gujarat. It has also been observed that the calculated hazard is sensitive to the $b$-value. The variation in hazard computed with respect to $b$-value is highest for Ahmedabad city and lowest for Bhuj city. Based on the present study, the recommended PGA values for the cities studied are $0.13 \mathrm{~g}, 0.15 \mathrm{~g}, 0.64 \mathrm{~g}, 0.14 \mathrm{~g}$ and $0.2 \mathrm{~g}$ for Ahmedabad city, Surat city, Bhuj city, Jamnagar city and Junagadh city, respectively. Deterministic spectra have been prepared for each major city for the 50th and 84th percentiles of ground motion occurrence in order to aid the performance-based designs. Close examination of the developed spectra has revealed that the expected ground motion values become high for the Kachchh region i.e. Bhuj city and moderate in the Mainland Gujarat, i.e. the cities of Surat and Ahmedabad. The seismic ground motion level in Saurashtra is moderate but differs only marginally from that presently specified in IS:1893-Part I (2002), i.e. for the city of Jamnagar the hazard presently specified is overestimated whereas it is underestimated for Junagadh city by IS:1893Part I (2002). The present provisions in code IS:1893-Part I (2002) are intensity based observations and do not address the probabilistic estimation of seismic hazard. 
The proposed spectra for the various major cities offer practical value to the engineers for seismic design of structures. The users of the proposed spectra should be cautious that the spectra presented in the present study are for the bedrock level. It is necessary to carry out site response analysis for the sites underlain by soil to compute the maximum horizontal ground acceleration required for the design of earthquake- resistant structures. It is also noteworthy that earthquake return periods are not presently addressed in this study and that the fault recurrence relations are obtained empirically from the regional recurrence further calculated from the earthquake catalogue for $M_{\mathrm{w}} \geq 4$. Furthermore, it is planned to develop probabilistic seismic hazard maps for the Gujarat region and site-specific spectra for a few critical locations to help safe and economical planning.

Acknowledgements. Authors are grateful to two anonymous reviewers for the constructive comments that enhanced the quality of the paper.

Edited by: M. E. Contadakis

Reviewed by: two anonymous referees

\section{References}

Abrahamson N. A. and Silva W. J.: Empirical Response Spectral Attenuation Relations for Shallow Crustal Earthquakes, Seismol. Res. Lett., 68, 1, 94-127, 1997.

Anbazhagan P., Vinod, J. S., and Sitharam, T. G.: Probabilistic seismic hazard analysis for Bangalore, Nat. Hazards, 48, 2, 145-166, 2009.

Ashara L. V., Patel J. N., Abdul Hamid, Srivastava, S., and Kumar, S.: Broadband seismic network for Gujarat, Proc. of 13th Symposium on Earthquake Engineering, IIT Roorkee, 1, 52-57, 2006.

Avadh Ram and Rathor, H. S.: On Frequency Magnitude and Energy of Significant Indian Earthquakes, Pure Appl. Geophys., 79, 26-32, 1970.

Bapat, A., Deshpande N. V., Das P. B., and Bhavnarayana, V.:Preimpoundment seismicity studies around Sardar Sarovar Site, CBIP 55, R\&D Session, 1989.

Bendick, R., Bilham, R., Fielding, E., Gaur, V.K., Hough, S.E.,Kier, G., Kulkarni, M.N., Martin, S., Mueller, K., and Mukul, M.: The January 26, 2001 Republic Day Earthquake, India, Seismol. Res. Lett., 72, 328-335, 2001.

Bhatia, S. C., Kumar, R., and Gupta, H. K.: A probabilistic seismic hazard map of India and adjoining regions, Ann. Geofis., 42, 1153-1164, 1999.

Bhattacharya, S. N., Karanth, R. V., Dattatryam, R. S., and Sohoni, P. S.: Earthquake sequence in and around Bhavnagar, Saurashtra, western India during August-December 2000 and associated tectonic features, Curr. Sci. India, 86, 25, 2004.

Bilham R., Gaur V. K., and Molnar, P.: Himalayan seismic risk, Science, 293, 1442-1444, 2001.

Bilham, R.: Earthquakes in India and the Himalaya: tectonics, geodesy and history, Ann. Geophys., 47, 2/3, 2004, http://www.ann-geophys.net/47/2/2004/.
Biswas, S. K. and Deshpande, S. V. :Geological and tectonic maps of Kutch, ONGC Bull., 1970, 7, 115-116, 1970.

Biswas, S. K.: Rift basins in western margin of India and their hydrocarbon prospects with special reference to Kutch basin, Am. Assoc. Petr. Geol. B., 66, 1, 497-1,513, 1982.

Biswas S. K.: Regional tectonic framework, structure and evolution of the western marginal basins of India, Tectonophysics, 135, 307-327, 1987.

Biswas, S. K.: A review of structure and tectonics of Kutch basin, western India, with special reference to earthquakes, Current Since, 88, 10 1592-1600, 2005.

Bonilla, M. G., Mark, R. K., and Lienkaemper, J. J.: Statistical relations among earthquake magnitude, surface rupture length and surface fault displacement, Bull. Seism. Soc. Am, 74, 23792411, 1984.

Boore, D. M., Joyner, W. B. and Fumal, T. E.: Equations from estimating horizontal response spectra and peak acceleration from Western North American earthquakes: a summary of recent work, Seismol. Res. Lett., 68, 128-153, 1997.

Campbell, K. W.: Empirical Near-Source Attenuation Relationships for Horizontal and Vertical Components of Peak Ground Acceleration, Peak Ground Velocity, and Pseudo-Absolute Acceleration Response Spectra, Seismol. Res. Lett., 68, 1, 154-179, 1997.

Cramer, C. H. and Wheeler, R. L.: The 2001 Gujarat, India earthquake and seismic hazard in Central and Eastern North America, Abstr. Seismol. Res. Lett., 72, 396, 2001.

Chandra, U.: Earthquakes of peninsular India-A seismotectonic study, Bull. Seismol. Soc. Am., 67, 1387-1413, 1977.

Chopra Sumer, Dinesh Kumar., and Rastogi, B. K. : Estimation of strong ground motions for 2001 Bhuj $\left(M_{\mathrm{W}}=7.6\right)$, India earthquake, Pure Appl. Geophys. Earth and Env. Sci., 167, 13171330, 2010.

Choudhury, D. and Shukla, J.: Probability of occurrence and study of earthquake recurrence models for Gujarat state in India, Dis. Adv., 4, 47-59, 2011.

Chung, W. Y.: Source parameters of two rif-associated intraplate earthquakes in peninsular India: the Bhadrachalam earthuake of April 13, 1969 and the Broach earthquake of March 23, 1970, Tectonophysics, 225, 219-230, 1993.

Chung, W. Y. and Gao, H.: Source parameter of the Anjar earthquake of July 21, 1956, India, and its seismotectonic implications for the Kutch rift basin, Tectonophysics, 242, 281-292, 1995.

Cornell, C. A.: Engineering Seismic Risk Analysis, Bull. Seism. Soc. Am., 58, 5, 1583-1606, 1968.

Frankel, A., Mueller, C., Barnhard, T., Perkins, D., Leyendecker, E. V., Dickman, N., Hanson, S., Hopper, M., :National seismic hazard maps: documentation June 1996,. Open-File Report (United States Geological Survey), 96-532, 41, 1996.

Gaur, V. K. and Chauhan, R. K. S.: Quantitative measures of seismicity applied to Indian regions, Bull Indian, Soc. Earth. Tech., 5, 63-78, 1968.

Guha S. K. and Basu, P. C.: Catalogue of earthquake $(M>3)$ in Peninsular India, Atomic Energy Regaulatory Board, Tech Document No. TD/CES-1, 1-70, 1993.

Gupta, H. K. and Rastogi, B. K.: Dams and Earthquakes, Elsevier, Amsterdam, 229, 1976.

Gupta, I. D.: The of the art in seismic hazard analysis, ISET Journal of Earthquake Technology, 39, 331-346, 2002. 
Gutenberg B. and Richter, C. F.: Frequency of earthquakes in California, Bull. Seism. Soc. Am., 34, 185-188, 1944.

GSI: Seismotectonic Atlas of India and its Environs, Geological Survey of India, Spec. Publ. No., 59, Kolkatta, 2000.

Hough, S. E., Martin, S., Bilham, R., and Atkinson, G. M.: The 26 January 2001, M 7.6 Bhuj, India, earthquake: observed and predicted ground motions, Bull. Seism. Soc. Am., 92, 2061-2079, 2002.

IS:1893-Part-I, Criteria for Earthquake Resistant Design of Structures, Bureau of Indian Standard, New Delhi, India, 2002.

Iyengar, R. N., Sharma, D., and Siddiqui, J. M.: Earthquake history of India in medieval times, Indian J. Hist. Sci., 3, 181-237, 1999.

Iyengar, R. N. and Ghosh, S.: Microzonation of earthquake hazard in greater Delhi area, Current Sci. India, 87, 1193-1202, 2004.

Iyengar, R. N. and Rghu Kanth, S. T. G.:Attenuation of ground motion in Peninsular India, Seismol. Res. Lett., 79, 67-81, 2004.

Jaiswal, K. and Sinha, R.: Probabilistic seismic-hazard estimation for peninsular India, Bull. Seismol. Soc. Am., 1, 318-330, 2007.

Johnston, A. C. and Kanter, L. R.: Earthquakes in stable continental crust, Sci. Am., 262, 69-75, 1990.

Johnston, A. C.: Compression tectonics in failed continental rifts: the India Republic Day and 7 February 1812 New Madrid earthquakes, Abstr. Seismol. Res. Lett., 72, 398, 2001.

Kaila, K. L., Gaur, V. K., and Hari Narain: Quantitative seismicity maps of India, B. Seismol. Soc. Am., 62(5), 1119-1132, 1972.

Kaila, K. L., Krishna V. G., and Mall, D. M.:Crustal structures along Mehmadabad - Billimora profile in the Cambay basin, India, from deep seismic soundings, Tectonophysics, 76, 99-130, 1980.

Karanth ,R. V. and Sant, D. A.: Lineaments and dyke swarms of lower Narmada Valley and southern Saurashtra, western India, J. Geol. Soc. India, 33, 425-434, 1995.

Khattri, K. N., Rogers, A. M., Perkins, D. M., and Algermissen, S. T.: A Seismic Hazard Map of India and Adjacent Areas, Tectoniphysics, 108, 93-134, 1984.

Krinitzsky, E. L.: How to obtain earthquake ground motions for engineering design, Engrg. Geol., 65, 1-16, 2002.

Krinitzsky, E. L.: Deterministic versus probabilistic seismic hazard analysis for critical structures, Internat. J. Eng. Geol., 40, 1-7, 1995.

Lettis, W. R. and Hengesh, J. V.: Preliminary observation on the origin and effects of the January 26, 2001 Republic Day earthquake, India 2001, Seismol. Res. Lett. 72, 396, 2001.

Malik, J. N., Sohoni, P. S., Karanth, R. V., and Merh, S. S.:Modern and Historic Seismicity of KachchhPeninsula, Western India, J. Geol. Soc. India, 54 545-550, 1999.

Mark, R. K.: Application of linear statistical model of earthquake magnitude versus fault length in estimating maximum expectable earthquakes, Geology, 5, 464-466, 1977.

Menon, A., Ornthammarath, T., Corigliano, M., and Lai, C. G. : Probabilistic seismic hazard macrozonation of Tamil Nadu in Southern India,BSSA, 100, 3, 1320-1341, 2010.

Nowroozi, A. A.: Emperical relations between magnitudes and fault parameters for earthquakes in Iran,Bull. Seism. Soc. Amer., 75, 1327-1338, 1985.

Nuttli, O. W.: Seismicity of the central United States, Geological Society of America, Rev. Eng. Geol., 4, 67-93, 1979.

Oldham, T. :A catalogue of Indian earthquakes from the earliest time to the end of A.D. 1869, Mem Geol. Surv. India 19, 53,
1883.

Parvez, A. I., Franco Vaccari, and Panza, G. F.: A deterministic seismic hazard map of India and adjacent areas, Geophys. J. Internat., 155, 489-508, 2003.

Petersen, M. D., Rastogi, B. K., Schweig, G. E.S., Harmsen, S. C., and Gomberg, J. S.: Sensitivity analysis of seismic hazard for the northwestern portion of the state of Gujarat, India, Tectonophysics, 390, 105-115, 2004.

Quittmeyer, R. C. and Jacob, K. H.: Historical and modern seismicity of Pakistan, Afghanistan, northwestern India, and southeastern Iran, Bull. Seismol. Soc. Am. 69 (3), 773-823, 1979.

Rajendran, C. P. and Rajendran, K.: Characteristics of deformation and past seismicity associated with the 1819 Kutch earthquake, Northwestern India, Bull. Seismol. Soc. Am., 91, 407426, 2001.

Rajendran, K., Rajendran, C. P., Thakkar, M., and Tuttle, M.: The 2001 Kutch (Bhuj) earthquake: Coseis- mic surface features and their significance, Curr. Sci. India, 80, 1397-1405, 2001.

Rajendran, C. P., Rajendran, K., Vora, K. H., and Gaur, A. S.: The odds of a seismic source near Dwarka, NW Gujarat: An evaluation based on proxies, Current Sci. India, 84, 5, 695-701, 2003.

Rao, B. R. and Rao, P. S.: Historical seismicity of peninsular India, B. Seismol. Soc. Am., 74, 2519-2533, 1984.

Rastogi, B. K.: Ground deformation study of $M_{W} 7.7$ Bhuj earthquake of 2001, Episode, 24 (3), 160-165, 2001.

Rastogi, B. K.: Damage due to the $\mathrm{M}_{\mathrm{w}} 7.7$ Kutch, India earthquake of 2001, Tectonophysics, 390, 85-103, 2004.

Raghu Kanth, S. T. G., and Iyengar, R. N.: Seismic hazard estimation for Mumbai city, Curr. Sci. India, 11, 1486-1494, 2006.

Raghu Kanth, S. T. G. and Iyengar, R. N.: Estimation of seismic spectral acceleration in peninsular India, J. Earth Sys. Sci., 3, 199-214, 2007.

Rao, Buddha Ramalineswara: Historical seismicity and deformation rates in the Indian Peninsular Shild, J. Seismology, 4, 247258, 2000.

Ravi Kumar, M. and Bhatia, S. C.: A new seismic hazard map for the Indian plate region under the global seismic hazard assessment programme, Current Sci. India, 77 (3), 447-453, 1999.

Schweig, III, E., Gomberg, J., Petersen, M., Ellis, M., Bodin, P., Mayrose, L., and Rastogi, B. K.: The M 7.7 Bhuj earthquake: global lessons for earthquake hazard in intra-plate regions, J. Geol. Soc. India, 61, 277-282, 2003.

Sadigh, K., Chang, C. Y., Egan, J. A., Makdisi, F., and Youngs, R. R.: Attenuation relations for shallow crustal earthquakes based on California strong motion data, Sesmol. Res. Lett. I(68), 180189, 1997.

Seed, H. B.: The selection of design earthquake for critical structures, Bull. Seism. Soc. Am., 72, 74-89, 1982.

Sitharam, T. G. and Anbazhagan, P.: Seismic Hazard Analysis for the Bangalore Region, Nat. Hazards, 40, 261-278, 2007.

Slemmon, D. B.: Determination of earthquake size from surface faulting events, Proc. Inter. Seminar on Seismic Zoning, China, 1989.

Sukhtankar, R. K., Pandian, R. S., and Guha, S. K.: Seismotectonic studies of coastal areas of Inida, Pakistan, Bangladesh and Burma, Nat. Hazards, 7, 201-210, 1993.

Talwani, P. and Abhijit Gangopadhyay: Tectonic Framework of the Kachchh Earthquake of 26 January 2001, Seism. Res. Lett., 72, 336-345, 2001. 
Tandon, A. N. and Srivasta, H. N.: Earthquake occurrences in India, Earthquake Engineering, Jai Krishna Volume, Sarita Prakashan (publ.), 1-48, 1974.

Tandon, A. N.: The rann of Kutch earthquake of 21 st July 1956, Indian J. Met. Geophys., 10, 137-146, 1959.

Thakur, V. C. and Wesnousky, S. G.: Seismotectonics of 26 January 2001 Bhuj earthquake affected region, Current Sci. India, 82, 4, 396-399, 2002.

Tripathi, J. N.: Probabilistic assessment of earthquake recurrence in the January 26, 2001 earthquake region of Gujarat, India, J. Seismol., 10, 119-130, 2006.

Toro, G. R. Abrahamson, N. A., and Schneider, J. F.: Model of strong ground motions from earthquakes in central and eastern North America: best estimates and uncertainties, Seismol. Res. Lett., 68, 41-58, 1997.

Tinti, S. and Mulargia, F.: Completeness analysis of a seismic catalog, Ann. Geophys., 407-414, 1985.
Vipin, K. S., Anbazhagan, P., and Sitharam, T. G.: Estimation of peak ground acceleration and spectral acceleration for South India with local site effects: probabilistic approach, Nat. Hazards Earth Syst. Sci., 9, 865-878, 2009, http://www.nat-hazards-earth-syst-sci.net/9/865/2009/.

Yadav, R. B. S., Tripathi, J. N., Rastogi, B. K., and Chopra, S.: Probabilistic Assessment of Earthquake Hazard in Gujarat and Adjoining Regions of India, Pure Appl. Geophys., 165, 18131833, 2008.

Yadav, R. B. S., Papadimitriou, E. E., Karakostas, V. G., Shanker, D., Rastogi, B. K., Chopra, S., Singh, A. P., and Kumar, Santosh: The 2007 Talala, Saurashtra, western India earthquake sequence: Tectonic implications and seismicity triggering”, J. Asian Earth Sci., 2010.

Wells, D. L. and Coppersmith, K. J.: Updated empirical relationships among magnitude, rupture length, rupture area and surface displacement", B. Seism. Soc. Am., 84, 4-43, http://www.isr. gujarat.gov.in, 1994. 